\title{
Genetic Testing in Male Infertility
}

\author{
Rima Dada ${ }^{*}, 1$, Jayapalraja Thilagavathi ${ }^{1}$, Sundararajan Venkatesh ${ }^{1}$, Sandro C. Esteves ${ }^{2}$ and \\ Ashok Agarwal ${ }^{3}$
}

${ }^{1}$ Laboratory for Molecular Reproduction and Genetics, Department of Anatomy, All India Institute of Medical Sciences, New Delhi, India

${ }^{2}$ ANDROFERT, Andrology and Human Reproduction Clinic, Campinas, Brazil

${ }^{3}$ Center for Reproductive Medicine, Cleveland Clinic, Cleveland, USA

\begin{abstract}
Infertility is a major health problem which affects approximately $22 \%$ of married couples in reproductive age. The apparent increased incidence of male infertility, in parallel with the widespread use of in vitro fertilization (IVF), raises concern as to the impact of advanced assisted conception techniques in transmitting genetic anomalies to the offspring. Recent research has widely focused on genetic factors underlying male infertility and several genetic tests are now clinically available. Genetic testing plays an important role not only to identify the etiology of male infertility but also aids in counseling as well as in the prevention of the transmission of genetic defects to the offspring via assisted reproduction. This review is focused on the syndromic and non-syndromic causes of male infertility and the diagnostic tests use in their evaluation.
\end{abstract}

Keywords: Male infertility, genetic testing, diagnosis, assisted reproductive techniques, review.

\section{INTRODUCTION}

Infertility, a genetically heterogeneous disorder with multifactorial etiology affects approximately $22 \%$ of couples in reproductive age group and has a major impact on reproductive health [1]. In about $50 \%$ of these cases the underlying problem lies in the male either solely or in combination with female factor. In males, the main causes of infertility include anatomical defects, gametogenesis dysfunction, endocrinopathies, immunological problems, ejaculatory failure and environmental toxicity [2]. Infertile men may present with phenotypical abnormalities or with sperm abnormalities. Phenotypic abnormalities include Klinefelter syndrome (KFS), congenital absence of vas deferens (CAVD), Kallmann syndrome (KS), cryptorchidism, hypospadias, ambiguous genitalia, and androgen insensitivity syndrome (AIS). Otherwise infertile men are considered as having idiopathic or unexplained infertility as they present with or without abnormal sperm parameters, respectively. Both phenotypic and non-phenotypic abnormalities have long been accepted as important causes of male infertility [3]. Hence genetic studies as either cytogenetic analysis or detection of specific gene mutations have been incorporated in most of the male infertility screening protocols. Recently, the role of sperm DNA damage has also been highlighted both in primary infertility (PI) and recurrent spontaneous abortions (RSA) following natural and assisted conception. In general, DNA damage cannot be detected by routine cytogenetic and molecular methods. As such, special tests

*Address correspondence to this author at the Department of Anatomy, All India Institute of Medical Science (AIIMS), New Delhi 110029, India; Tel: 91 26593517; Fax: 91-1126588663;

E-mail: rima_dada@rediffmail.com such as Comet assay, sperm chromatin dispersion assay (SCD), transferase-mediated dTUP nickend labeling (TUNEL), or sperm chromatin structure assay (SCSA) have been developed. Tests to assess DNA damage are of great importance to understand the etiology of both idiopathic infertility and idiopathic RSA as DNA damage in the sperm can be transmitted to the offspring and may potentially increase the risk for transgenerational infertility or other serious health problems such as congenital malformations and childhood cancer [4].

Genetic screening includes cytogenetic analysis to detect numerical and structural chromosomal rearrangements, analysis of single gene mutations and assessment of nonspecific DNA damage. Research on reproductive genetics has recently expanded fueled by the increased demand of couples attending infertility clinics and opting for advanced assisted reproduction techniques. Intracytoplasmic sperm injection (ICSI) has revolutionized the management of infertility, is developed to circumvent the inability of sperm to fertilize an egg. The major concern with regard to ICSI is that it bypasses all natural selection mechanisms that sperm encounter during their course to fertilize the oocyte and may aid in the transmission of paternal-derived genetic anomalies to the offspring. Due to the association of ICSI with increased incidence of neurological and genitourinary abnormalities, major congenital abnormalities and low birth weight [5], identification of genetic abnormalities has become an integral step for the proper management in infertile subjects seeking such treatment. As such, genetic screening should be considered as part of the diagnostic workup in ART candidates. This review focuses on the various possible genetic causes of male infertility and the tests involved in their diagnosis. 


\section{CYTOGENETIC ABNORMALITIES}

Cytogenetic analysis is the most often used diagnostic genetic test for the evaluation of men with severe oligozoospermia and azoospermia $[1,6]$. Karyotyping involves collection of heparinized peripheral blood (approximately 5 $\mathrm{ml}$ ) and isolation of the plasma lymphocyte suspension. Lymphocytes are transferred to a culture media (RPMI) containing a mitotic stimulator (PHA) and the mixture is then incubated for 72 hours. After 70 hours cell division is arrested at the metaphase stage by using colchicine. Cells are then subjected to hypotonic treatment $(\mathrm{KCl})$ and are fixed with carnoy's fixative overnight at $4^{\circ} \mathrm{C}$. Finally, cells are spread onto a clean grease free wet slide and subjected to GTG banding for karyotyping. The standard protocols are available in various guidelines and should be optimized for respective laboratory conditions [7].

Chromosomal defects are the most common genetic abnormalities in infertile men [8]. The reported incidence of cytogenetic abnormalities in infertile males ranges from $2.1 \%$ to $15.5 \%$ [9-13]. Patients with chromosomal anomalies display severely compromised semen quality ranging from azoospermia to severe oligozoospermia. Klinefelter syndrome (KFS) is the major cytogenetic/sex chromosomal/ numerical anomaly detected in infertile men followed by translocations, deletions and inversions.

\section{Klinefelter Syndrome (KFS)}

Men presenting with Klinefelter syndrome have a 47, XXY chromosomal complement in all cells or are 'mosaic' [14-25]. The 47, XXY karyotype of KFS arises spontaneously when paired $X$ chromosomes fail to disjoin in the first or second phase of meiosis during oogenesis or spermatogenesis. The presence of two X chromosomes in KFS leads to seminiferous tubule dysgenesis in approximately one-third KFS cases. The failed inactivation of X chromosome in KFS is the most plausible reason for impaired spermatogenesis in these patients. Chromosome complement is usually identified by conventional GTG banding and karyotyping. The frequency of Klinefelter syndrome (KFS) is $0.2 \%$ of male newborns and $11 \%$ azoospermic men [14]. In its non-mosaic form, Klinefelter syndrome is associated with elevated serum FSH levels. The sterility in KFS is due to the high prevalence of azoospermia, seen in $92 \%$ of KFS men able to provide a semen sample, with the remainder having a median of 0.1 million sperm $/ \mathrm{mL}$. It has also been reported that there is a progressive decline in spermatogenesis in men with KFS and hence early sperm retrieval or sperm banking (if possible) is advocated in such cases [26].

Nevertheless, focal areas of spermatogenesis may be present within the testis of azoospermic men with KFS, and sperm can be retrieved in approximately $50 \%$ of cases on testicular exploration. In such cases, ICSI can be performed with an estimated success rate ranging from $30 \%$ to $50 \%$ [14]. As in other men with non-obstructive azoospermia, none of the clinical parameters are predictive of success in sperm retrieval. The majority of babies born from 47, XXY fathers have been normal although chromosomally abnormal fetuses have also been reported [15-17]. Recently, Sciurano et al. (2009) have shown that seminiferous tubules with germ cells represent only a minor fraction (8-24\%) of all tubules in men with non-mosaic Klinefelter syndrome [18]. Using fluorescence in situ hybridization (FISH) with probes for the $\mathrm{X}$-centromere and immunolocalization of meiotic proteins, they showed that all the 92 meiotic spermatocytes analyzed with FISH were euploid, 46, XY, and thus can form normal, haploid gametes. On the other hand, Sertoli cells showed two signals for the $\mathrm{X}$ chromosome, meaning that they were 47 , $\mathrm{XXY}$. These new findings may explain the high rate of normal children born after testicular sperm extraction plus ICSI when applied to Klinefelter patients. The authors of this aforementioned study speculated that spermatogenic foci most probably originated from clones of spermatogonia that have randomly lost one of the $\mathrm{X}$ chromosomes, probably during periods of life when high spermatogonial mitotic activity occurred. Nonetheless, FISH analysis has demonstrated that the frequency of aneuploidy for the sex chromosomes varies from $1.5 \%$ to $7 \%[19,20]$ in sperm from Klinefelter mosaics, and from $2 \%$ to $45 \%[12,21,22]$ in the sperm of men who appear to have a non-mosaic 47 , XXY karyotype. Therefore, preimplantation genetic diagnosis using advanced FISH technique can be used to select normal embryos in KFS with sperm production.

The clinical features of androgen deficiency in KFS provide a complete spectrum of male reproductive health and its diverse disorders. A crucial issue is whether prior testosterone treatment, required to rectify lifelong androgen deficiency, has deleterious effects on spermatogenesis, thereby reducing chances of TESE sperm pickup. Sperm retrieval rate appeared to be lower $(20 \%)$ in men who previously received exogenous androgens [14]. These findings argue against the routine treatment of Klinefelter patients with testosterone therapy at the time of diagnosis. Such treatment may suppress the hypothalamic-pituitarytestis axis, impairing FSH secretion and causing decreased intratesticular androgen levels that could impair spermatogenesis. Return of spermatogenesis after testosterone pretreatment may be irreversible or require a washout and recovery period of several years. Therefore, the concern for maintenance of fertility potential in young men with Klinefelter syndrome must be balanced with potential benefits of testosterone replacement, including the possible psychosocial benefits of early androgen replacement therapy in these patients. On the other hand, other medication leading to endogenous testosterone increase seems to be beneficial to KFS men seeking fertility. A recent study by Ramasamy et al. (2009) assessed the potential predictive factors for successful sperm retrieval (SR) in patients with KFS. They showed that men with KFS with either normal or low baseline testosterone but who respond to medical therapy had a better chance of sperm retrieval. In their study, a total of 68 men with non-mosaic KFS underwent 91 microdissection testicular sperm extraction (TESE) attempts. Men with serum testosterone levels of $<300 \mathrm{ng} / \mathrm{dL}$ received medical therapy (aromatase inhibitors, clomiphene or human chorionic gonadotropin) prior to micro-TESE. Patients who responded to medication with a resultant testosterone of 250 $\mathrm{ng} / \mathrm{dl}$ or higher had higher SR rate than men in whom post treatment testosterone was less than $250 \mathrm{ng} / \mathrm{dl}(77 \%$ vs. 55\%) [16]. Sperm retrieval rates were similar irrespective of the type of preoperative hormonal therapy, but the best SR rates $(86 \%)$ were achieved in men with normal baseline testosterone levels. 


\section{Autosomal Translocation}

Autosomal translocations occur in 1 in 500 live births and is the most commonly observed structural chromosomal anomaly in infertile men. Autosomal translocations impair spermatogenesis due to disrupted meiotic pairing and segregation [27-31]. Autosomal translocations are 4 to 10 times more common in infertile men than in the fertile population $[32,33]$. Most translocations have no effect on other tissues but can severely impair spermatogenesis. This may be due to disruption of genes responsible for spermatogenesis or due to impaired synaptic complex pairing during meiosis [34]. In cases of autosomal translocation, the percentage of balanced and unbalanced gametes using meiotic segregation analysis was determined by fluorescence in situ hybridization (FISH) $[35,36]$. Carriers with unbalanced reciprocal translocation have a higher risk of producing unbalanced gametes or offspring with abnormalities. Studies also suggest that unpaired regions, regardless of whether or not they pair with the sex chromosomes, are transcriptionally silenced during meiosis in reciprocal translocation carriers. If genes critical for meiosis are present in the asynapsed regions, meiotic arrest is likely to occur. Both the chromosomes involved in translocation and location of the breakpoints are likely to be determining factors for the fidelity of synapsis, and thus for the fertility status of the carrier [34]. These types of translocation carriers always have reduced number of gametes with an unbalanced karyotype [37].

\section{Sex-chromosome Translocation}

The autosome translocation occurs approximately in 1 in 2,000 individuals in the general population [38, 39]. Like other chromosomal translocations any part of the sex chromosome may translocate to autosomes. Translocations involving sex chromosomes have direct consequences on genes required for germ cell differentiation. Translocations between the $\mathrm{Y}$ and autosomes are rare and may involve any part of the $\mathrm{Y}$ chromosome, often leading to abnormal spermatogenesis and hence infertility [40, 41]. The proposed mechanisms for impaired fertility due to sex chromosome translocation are the altered gene loci or impaired formation of sex vesicle during meiosis. During meiosis I of spermatogenesis, pairing between the $\mathrm{X}$ and $\mathrm{Y}$ chromosomes occurs in primary spermatocytes at the zygotene and pachytene stages, resulting in a condensed sex vesicle. Pairing of sex chromosome appears to be distinct from autosome pairing as it is limited to the telomere pseudoautosomal regions (PARs), PAR1 (at Xp/Yp) and PAR2 (at Xq/Yq). Pairing between the sex chromosomes begins in Xpter and Ypter with synapses occurring in most parts of Yp and in the distal third of Xp. Deletions of pseudoautosomal sequences result in impaired pairing between the $\mathrm{X}$ and $\mathrm{Y}$ chromosomes, thus indicating that there is an obligatory recombination event in the DNA homologue segment located in Xpter and Ypter during meiosis I, which is essential to promote meiotic pairing and ensure sperm production [42]. Translocations involving a sex chromosome and an autosome are more capable of causing infertility than translocations involving autosomes. This is mainly due to the fact that derivative chromosomes interfere with normal sex and autosome homologue pairing and thus inhibit homologue segregation $[38,43]$.

\section{Robertsonian's Translocation (RT)}

Robertsonian's translocation or centric fusion is a translocation between two acrocentric chromosomes in which both chromosomes lose their $\mathrm{p}$ arms. It may lead to male infertility and is found in about 1 in 1,000 newborns [44]. Heterozygous carriers contribute significantly to genetic imbalance, fetal wastage, mental retardation, birth defects and fertility problems $[45,46]$. In heterozygous carriers, RT chromosomes and their acrocentric homologues may undergo either alternate segregation or adjacent segregations at meiosis. Alternate segregation results in the formation of balanced gametes carrying either the RT or the normal karyotype. In contrast, adjacent segregation leads to the formation of aneuploid gametes that are directly responsible for all of the associated phenotypes observed in heterozygous carriers and their offspring. It has been suggested that the most children conceived from fathers who are heterozygous for RT carry the translocation in balanced form [47]. Robertsonian translocation may in some way predispose to malsegregation and/or lack of normal embryo development [48]. PGD analysis showed that better quality embryos are formed from sperm of an RT carrier [49]. Consequently, occurrence of aneuploid embryos will lower the success rate of the IVF treatment $[50,51]$, increase the risk of an unbalanced translocation and alter the amount of genetic material in the offspring. Hence, preimplantation genetic diagnosis (PGD) may be useful for such couples undergoing IVF treatment. In Fig. (1), we present the distribution of cases with numerical, sex-chromosome, autosomal and Robertsonian translocation found in our laboratory (Fig. 1).

\section{MOLECULAR CYTOGENETIC ABNORMALITIES}

\section{Fluorescent in situ Hybridization (FISH)}

FISH is a molecular cytogenetic method employed to study specific loci or number of specific chromosomes (e.g., aneuploidies and deletions). It is based on the hybridization of loci/chromosome-specific DNA probes tagged with fluorochromes to the complementary DNA sequences for the region of interest. The fluorochromes are then visualized under the fluorescent microscope. Fluorochrome probes for centromere, telomere and whole chromosome (chromosome painting) are also available. Unlike conventional cytogenetic analysis, FISH does not require metaphase cells and can be worked out in the interphase nuclei. The technique can be used in sperm to detect aneuploidy. Sperm aneuploidies may result in severe sperm defects, infertility and abortion. The male partner of couples with increased number of ICSI/IVF failures and even recurrent spontaneous abortions (RSA) are found to have increased sperm aneuploidy rate [52]. In such cases it may be suggested to perform meiotic segregation analysis to know the percentage of sperm cells with normal chromosomal number. This may help to prevent the transmission of aneuploidies to the offspring and also to prevent abortions. FISH can be applied to any infertile men with severe sperm defects such as oligozoosperima, teratozoospermia or oligoasthenoteratozoospermia (OAT). In such cases it has been observed that sperm aneuploidies were inversely correlated to sperm quality. It has been shown that 


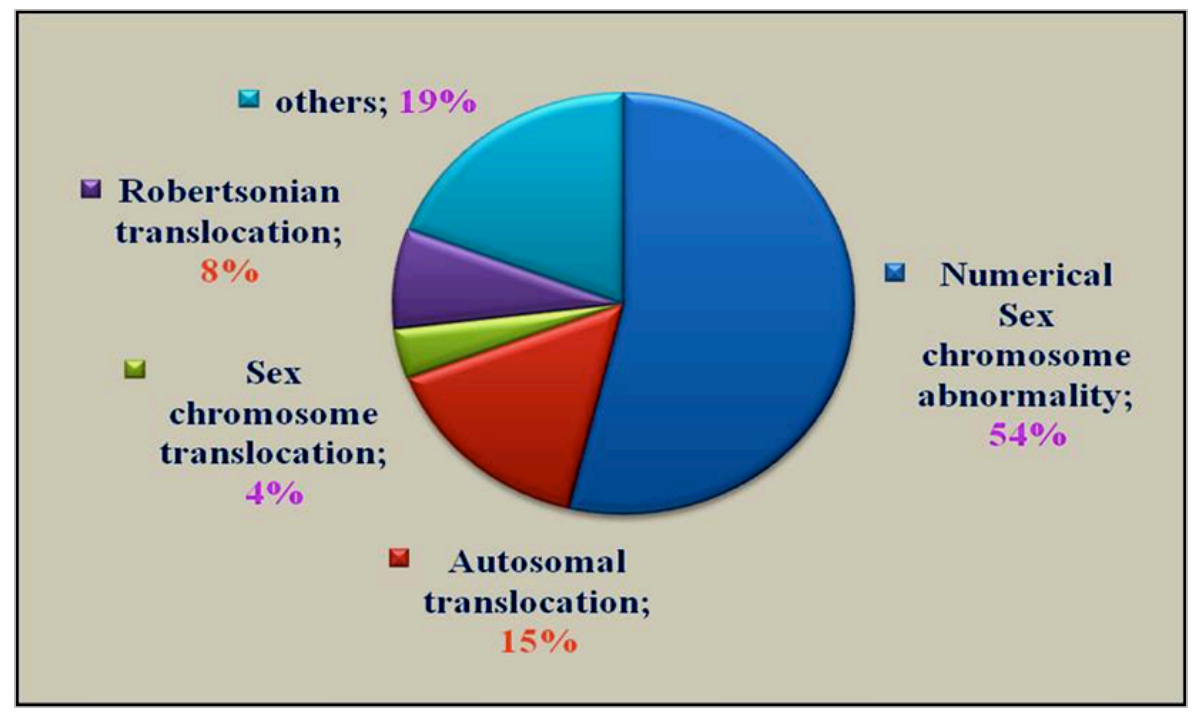

Fig. (1). Pie diagram showing distribution of the frequency of different types of cytogenetic anomalies in infertile men.

the analysis of chromosomes $21, \mathrm{X}$, and $\mathrm{Y}$ for aneuploidies was enough to identify at risk individuals [53]. Sperm aneuploidies are found even in the ejaculates and testicular sperm of fertile controls but the frequency is significantly lower compared to men with sperm defects [54]. Low success rate of ART in such cases may be due to the selection of aneuploid gametes for ART.

FISH is also an ideal method for detection of submicroscopic ( $<3 \mathrm{MB})$ rearrangements, cryptic and low level mosaicism. In addition, it is used as a confirmatory test for detecting the chromosomal anomalies after conventional karyotyping. Although FISH cannot select suitable sperm for ICSI, the percent of aneuploidies and meiotic segregation analysis may help to proper counsel infertile couples.

\section{Pre-Implantation Genetic Diagnosis (PGD)}

Though PGD is not a routine method in the evaluation of male infertility; it is often used to evaluate embryos derived from ART. PGD has a potential role to prevent the transmission of genetic anomalies to the offspring. The technique involves the isolation of one or two cells (blastomere) from a 3-day in vitro generated embryo, or multiple cells from a 5day blastocyst, to perform genetic analysis for aneuploidies or specific mutations by FISH or PCR. PGD is usually recommended for couples having a history of genetic disorders or suspected genetic defects. Infertile males undergoing IVF, such as those with severe sperm defects and KFS individuals with sperm production, may consider PGD analysis as part of their treatment management.

\section{Y Chromosome Microdeletion}

Y chromosome microdeletions are a relatively common cause of male infertility. It is characterized by azoospermia or severe $\left(<1 \times 10^{6}\right.$ sperm $/ \mathrm{mL}$ semen $)$ to moderate oligozoospermia ( $1-5 \times 10^{6} \mathrm{sperm} / \mathrm{mL}$ semen), but rare cases of mild oligozoospermia $\left(5-20 \times 10^{6} \mathrm{sperm} / \mathrm{mL}\right.$ semen) may occur. Males with $\mathrm{Y}$ chromosome infertility usually have no obvious symptoms, although physical examination may reveal small testes and/or cryptorchidism, or varicocele. A single study suggested that one of the deletions of the $\mathrm{Y}$ chromosome in AZFc region (designated gr/gr) also causes a slight increase in susceptibility to testicular germ cell tumors [55]. The prevalence of $\mathrm{Y}$ chromosome microdeletions is estimated to be about 1:2000 to 1:3000 males [56-59]. The frequency of deletion was found to be in the range of approximately $10 \%$ in Indian, European, Italian and French infertile population [56-59]. Despite that, a marked difference in the reported frequency of AZF deletions among patients with non-obstructive azoospermia, i.e., $10-12 \%$ in USA, Australia and Asia, 2-10\% in Europe, and 7\% in Brazil has been documented [58]. With the increased demand for Y-chromosome testing, it is apparent that different methods are used, particularly with regard to the sets of primers and number of sequence tagged sites (STS). To obtain uniform results it is necessary to follow strict guidelines, as those recommended by the European Academy of Andrology (EAA). Yq microdeletion analysis is usually carried out by multiplex polymerase chain reaction (PCR) amplifying $\mathrm{AZFa}, \mathrm{AZFb}$ and $\mathrm{AZFc}$ loci in the $\mathrm{q}$ arm of the $\mathrm{Y}$ chromosome [57]. PCR should be performed in duplicate and in the presence of internal control (SRY). Positive and negative control PCRs should run in parallel to validate the test. PCR is a rapid method for detection of submicroscopic $\mathrm{Y}$ chromosome deletions which are undetectable by conventional cytogenetic analysis. The EAA recommends the use of 7 set of markers (6 STS in AZF loci and 1 STS [sY14] for SRY as an internal control) in men with idiopathic infertility presenting with severe oligo and azoospermia.

The Yq chromosome loci is named azoospermia factor (AZFa, AZFb and ZFc) which comprise several genes such as USP9Y, DBY, RBMY, PRY and DAZ (Fig. 2). These genes are essential for spermatogenesis at different stages of germ cell development and their functions are tabulated (Table 1). Deletions of AZFa and AZFb are usually associated with Sertoli-cell-only syndrome (SCO) and maturation arrest, respectively [60]. AZFa is expressed in spermatogonial stem cells and AZFb in premeiotic germ cells (primary spermatocyte). Partial or complete AZFc loss is associated with a highly variable heterogeneous phenotype ranging from oligozoospermia to azoospermia, and testicular 


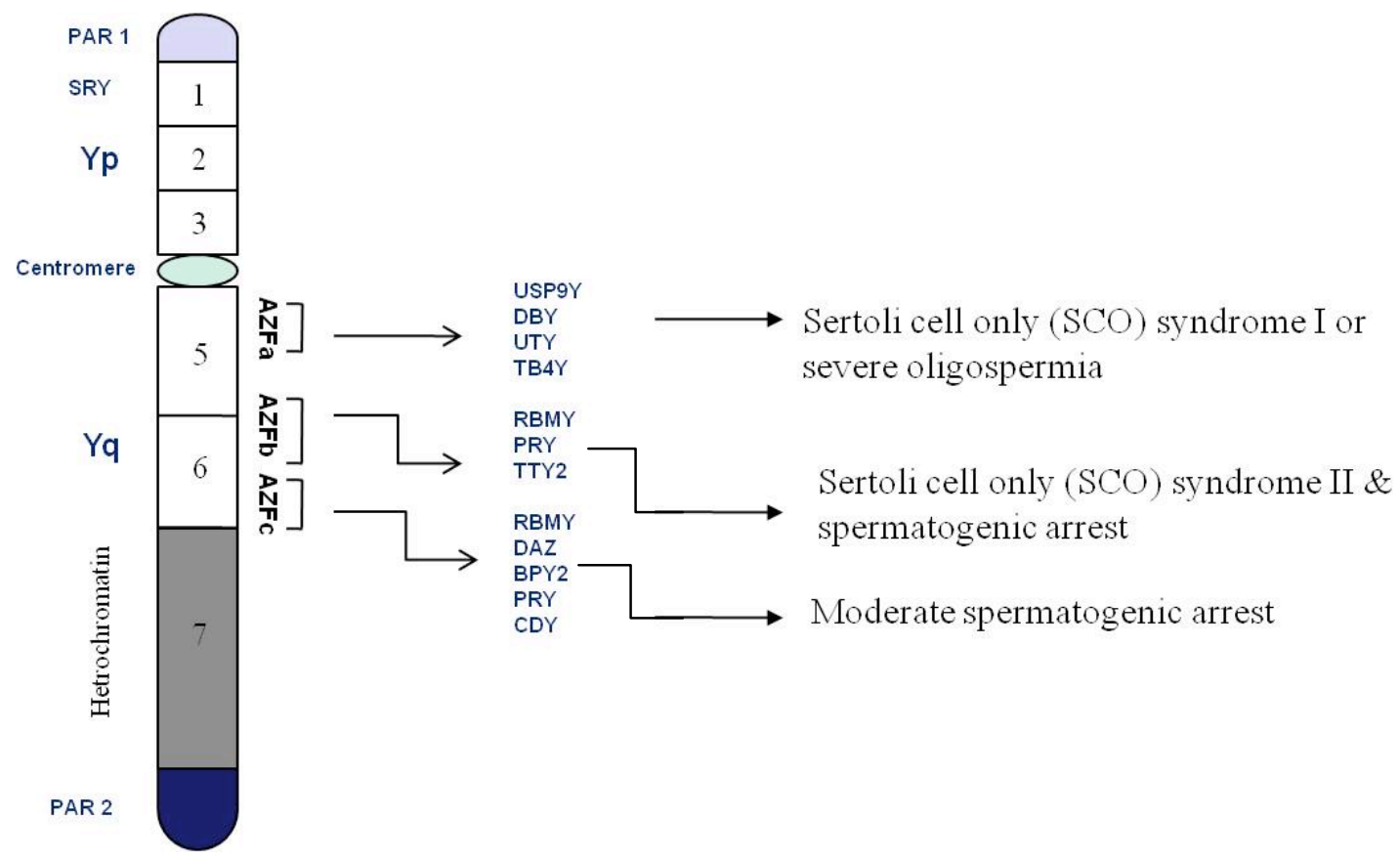

Fig. (2). Human Y Chromosome. PAR 2 is the region which undergoes end to end recombination with X chromosome. The illustration depicts SRY on Yp and AZF a, b, c on 5 and 6 Yq intervals with their main genes located in each locus.

histology showing Sertoli cell-only syndrome, maturation arrest or hypospermatogenesis. This is mainly due to presence of multiple copies of DAZ gene in AZFc and the presence of an autosomal homologue on 3p24 (DAZLA). Calogero et al. (2001) reported that Yq deletions are very rarely found in men with a sperm count above $5 \times 10^{6} / \mathrm{mL}$, whereas $8.2 \%$ of men with sperm counts below the aforementioned levels exhibit Yq deletions [61, 62]. It is well known that AZFa, AZFb and AZFc deletions are caused by intrachromosomal recombination events between large homologous repetitive sequences blocks located on Yq11 as this region is flanked by inverted repetitive element and palindromic sequences [63].

$\mathrm{Y}$ chromosome infertility is inherited in a Y-linked manner. Because males with deletion of the AZF region of the long arm of the $\mathrm{Y}$ chromosome are infertile, the deletions are usually de novo and therefore not present in the father of the proband. Rarely, within a family, the same deletion of the Y chromosome can cause infertility in some males but not in others; hence, some fertile males with deletion of the AZF regions have fathered sons who are infertile.

Screening for $\mathrm{Yq}$ microdeletions helps in better diagnosing male infertility and to expand the current knowledge on spermatogenesis. Y microdeletion screening is strongly recommended for infertile men with severe sperm defect of unknown origin (ranging from azoospermia to oligozoospermia). Such screening is mandatory for individuals fitting in the categories mentioned above who opt for ART because their male offspring will inherit the $\mathrm{Yq}$ microdeletion and infertility [64]. Besides, there is an increased risk of complete $\mathrm{Y}$ chromosome loss which leads to genital ambiguity. Female fetuses from a father with a Y chromosome loss have

Table 1. Important Genes on Various AZF Loci Associated with Spermatogenesis

\begin{tabular}{|c|c|c|c|}
\hline Location & Genes & Functions & Reason for Investigation \\
\hline \multirow[b]{2}{*}{$\mathrm{AZFa}$} & $\begin{array}{c}D B Y \\
(\text { dead box on the Y) }\end{array}$ & Plays an important role in spermatogenesis & $\begin{array}{l}\text { Involved in the development of premeiotic } \\
\text { germ cells }\end{array}$ \\
\hline & $\begin{array}{c}\text { USP9 } Y \\
\text { (ubiquitin-specific protease } 9, \mathrm{Y} \\
\text { chromosome) }\end{array}$ & $\begin{array}{l}\text { Role in the efficiency of protein turnover in } \\
\text { spermatogenesis }\end{array}$ & $\begin{array}{l}\text { Gene deletion is associated with azoospermia, } \\
\text { oligozoospermia or oligoasthenozoospermia }\end{array}$ \\
\hline \multirow[t]{2}{*}{$\mathrm{AZFb}$} & $\begin{array}{c}R B M Y \\
\text { (RNA binding motif on } \mathrm{Y} \text { ) }\end{array}$ & $\begin{array}{c}\text { Codes for RNA binding proteins involved in } \\
\text { splicing, metabolism and signal transduction } \\
\text { pathways }\end{array}$ & $\begin{array}{l}\text { Gene loss associated with spermatogenic } \\
\text { arrest }\end{array}$ \\
\hline & $\begin{array}{l}H S F Y 1 \text { and } H S F Y 2 \text { (Heat shock } \\
\text { transcription factor, Y-linked) }\end{array}$ & Possible role in spermatogeneis & Unknown \\
\hline $\mathrm{AZFb} / \mathrm{c}$ & $P R Y$ and $P R Y 2$ & $\begin{array}{l}\text { Regulates the apoptosis an essential process that } \\
\text { removes abnormal sperm }\end{array}$ & $\begin{array}{c}\text { Absence of this gene leads to spermatogenic } \\
\text { arrest }\end{array}$ \\
\hline $\mathrm{AZFc}$ & $\begin{array}{c}D A Z \\
\text { (Deleted in azoospermia) }\end{array}$ & $\begin{array}{l}\text { Regulates translation, code for germ cell specific } \\
\text { RNA binding proteins, controls meiosis, and } \\
\text { maintains primordial germ cell population }\end{array}$ & $\begin{array}{c}\text { Deletion of this gene causes a spectrum of } \\
\text { phenotypes ranging from oligozoospermia to } \\
\text { azoospermia }\end{array}$ \\
\hline
\end{tabular}


no increased risk of congenital abnormalities or infertility. In ART candidates at risk of having a son with $\mathrm{Y}$ chromosome deletion, PGD can be performed to determine the sex of the embryo and/or the presence of the Y chromosome deletion.

Alternatively, Yq microdeletion screening may be performed on sperm DNA rather than using blood DNA. It has been shown that the study of 43 STSs is sufficient to identify all the known deletion sites associated with male infertility $[65,66]$.

\section{Congenital Bilateral Absence of Vas deferens (CBAVD)}

Congenital bilateral absence of vas deferens (CBAVD) is a syndromic disorder characterized by vasa deferentia agenesis that accounts for at least $6 \%$ of obstructive azoospermia and approximately $2 \%$ of infertility cases. Cystic fibrosis transmembrane conductance regulator (CFTR) gene mutation is responsible for CBAVD in at least $95 \%$ of men [67]. Cystic fibrosis is a disorder characterized by chronic pulmonary disease, pancreatic exocrine insufficiency, and elevated concentrations of electrolytes in sweat. CFTR gene is located on the chromosome 7 , comprising $190 \mathrm{~kb}$ with 27 exons associated with over 1,500 mutations reported so far [68]. The expressed CFTR protein is a glycosylated transmembrane protein that functions as a chloride channel and expressed in epithelial cells of exocrine tissues, such as the lungs, pancreas, sweat glands and vas deferens. CBAVD has an autosomal recessive pattern of inheritance [69]. The common CFTR mutations are: i) $\triangle$ F508 (three nucleotides that encode the phenylalanine at position 508 are missing in the protein's amino acid sequence). $\Delta$ F508 represents $60-$ $70 \%$ of the CF mutations in carriers and patients; ii) polymorphisms within intron $8(5 \mathrm{~T}, 7 \mathrm{~T})$. Such polymorphisms reduce the production of the CFTR protein which results in a reduction of the splicing efficiency of the CFTR gene; and iii) the missense $\mathrm{R} 117 \mathrm{H}$ mutation in exon 4 . It is also related to CBAVD in association with the 5T variant [70]. Patients with CBAVD owing to CFTR mutations are at risk of having both male and female offspring with $\mathrm{CF}$ and male offspring with CBAVD. Recent data suggest that azoospermic men with idiopathic obstruction and those presenting with the triad of chronic sinusitis, bronchiectasis and obstructive azoospermia (Young Syndrome) have an elevated risk of CFTR mutation [71]. Hence, screening for CFTR mutations is recommended to such couples who opt for ART for determining the risk of transmitting CFTR mutations to the offspring. Nowadays different techniques such as blotting, in situ hybridization, fluorescence in-situ hybridization, single strand conformation polymorphism, hetroduplex analysis, PCR, real time PCR followed by direct sequencing have been developed for screening CFTR mutations. Up-to-date information CFTR gene mutations can be found at http:// www.genet.sickkids.on.ca/cftr/app, a CFTR mutation database. Direct sequencing for specific mutation or alleles may be advantageous [72] over other methods. PGD has been regarded as a useful tool to identify the presence of CFTR mutations in in vitro derived embryos given the fact that mutations have been screened in both male and female partners.

\section{Androgen Insensitive Syndrome (AIS)}

Androgen insensitivity syndrome (AIS) is a disorder involving Androgen Receptor (AR) function due to mutations in the AR gene. AR function is essential for the development of male phenotype and spermatogenesis. In normal males, androgens (testosterone [T]/dihydrotestosterone [DHT]) bind to the AR, forming a complex that activates the transcription of genes necessary for secondary sexual growth and spermatogenesis. Unlike other autosomal genes, AR gene is a single copy gene located on the $\mathrm{X}$ chromosome (Xq11-q12) containing eight exons. Exon 1 is the transactivation domain that activates the transcription, exon 2-3 is the DNA binding domain (DBD), exon-5-8 is the ligand binding domain (LBD) whereas exon 4 is the hinge region that connects $\mathrm{DBD}$ and $\mathrm{LBD}$ (Fig. 3). AR gene mutations can severely impair the amount, structure and function of the AR, thus causing AIS in which various phenotypes may be seen, such as ambiguous genitalia, partial labialscrotal fusion, hypospadias, bifid scrotum and gynaecomastia [73]. Mutations in this gene ranges from point mutations, insertions or deletions, or altered $\mathrm{CAG}$ repeats of AR gene. CAG repeats are present in the first exon of AR gene and contain an average of $21 \pm 2$ repeats. The CAG repeats are polymorphic and are reported to be either increased or decreased in infertile men [74], although altered CAG repeats are also associated with other diseases such as Kennedys disease, cancers (prostate, ovarian, etc), Alzheimer's disease and autism $[75,76]$.

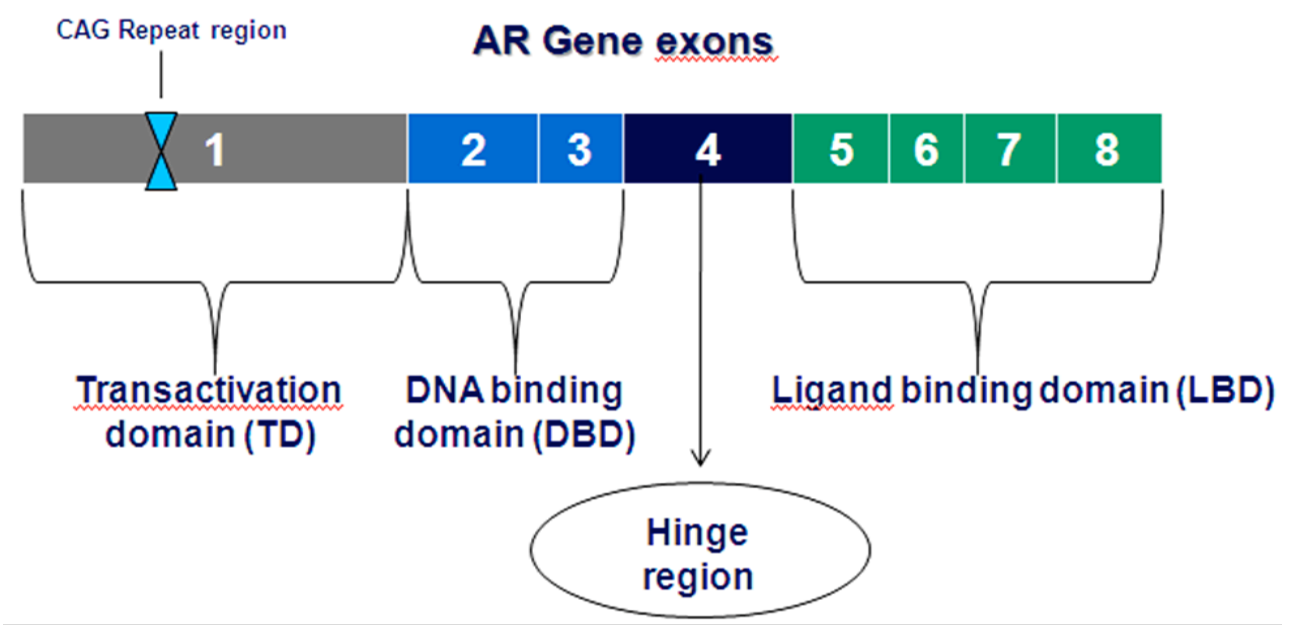

Fig. (3). AR gene exons and its functional domains. 
In male infertility, AR mutation is believed to affect at least $2 \%$ of men [77] and CAG repeats $(>28)$ in up to $35 \%$ of men [78]. Mutations in the AR gene may lead to a female phenotype, which varies depending on the severity of the AR gene mutations. Mutations in AR may also result in depressed spermatogenesis without any abnormalities in male secondary sexual characteristics [79]. There are no specific regions (except CAG repeats) or base changes which are particularly responsible for AIS. It is therefore recommended to screen the entire AR gene ( 8 exons) for mutations/ deletions using bi-directional sequencing in a male with normal 46,XY karyotype (46, XY) [80]. The direct sequencing of human AR gene $(A R)$ has allowed researchers to examine the effect of AR mutations on the development of the normal male phenotype including spermatogenesis [81]. Most of the mutations are described in the carboxy-terminal domain of AR, which includes exons 4 to 8 , that can lead to a defect in androgen binding and the loss of receptor function [82]. Screening for the CAG repeats in the AR gene is widely performed as they are the most often detected in patients with AIS [74, 82-84].

The overall fertility status of affected individuals with AIS depends not only on the AR sequence alteration but also on the emergent phenotype resulting from a dynamic interaction between the genome and proteome. Nevertheless, detailed characterization of the molecular mechanisms of AR dysfunction in AIS, together with a thorough phenotype profiling, may lead to effective therapy and useful genetic counseling for affected individuals and families. In view of the success of testicular sperm aspiration and the prospects of successful conception following ICSI in azoospermic men [85], screening for AR mutations and appropriate preconception counseling should be offered to subfertile men at risk of having AR mutations. The detailed up to date compilation of over 400 mutations of AR gene can be found at http://androgendb.mcgill.ca

\section{Steroid 5-alpha-Reductase 2 (SRD5A2) Deficiencies}

Steroid 5-alpha-reductase is an enzyme encoded by the SRD5A2 gene which comprises 5 exons and is located in chromosome $2 \mathrm{p} 23$. The main function of steroid 5-alphareductase is the conversion of testosterone into dihydrotestosterone (Fig. 4). In SRD5A2 deficiency, DHT levels are below normal range. DHT is important for development of the external genitalia (penis, scrotum) and testes descend to the scrotum while testosterone plays an important role during embryogenesis for the normal development and differentiation of internal male genitalia, including the epididymis, vas deferens and the seminal vesicles. At puberty and adult life, both androgens are involved in the development of male secondary sexual characteristics and spermatogenesis.

SRD5A2 deficiency $(5 \alpha-R D 2)$ is considered a rare autosomal recessive disorder caused by the mutation in the SRD5A2 gene. However, the prevalence of SRD5A2 gene mutations in the general population is unknown. Patients with SRD5A2 mutation may exhibit a female phenotype or a complex phenotype due to partial virilization that includes hypospadia, bifid scrotum, micropenis and urogenital sinus opening in the perineum.

Screening for SRD5A2 mutations are usually performed after the identification of abnormalities in other biochemical markers such as normal-to-high levels of serum testosterone (T), low DHT levels, or elevated T/DHT ratio. Approximately 67 mutations have been identified for the SRD5A2 gene. These include both nonsense and missense mutations, splice-junction alterations as well as entire gene deletion [86]. Although the prevalence of SRD5A2 mutations is not well known, p.R246Q mutation in exon 5 has been reported as a common mutation in 5-alpha-reductase deficient patients from the Indian subcontinent, including a novel heterozygous missense mutation p.Q56H and homozygous polymorphism p.V89L (exon 1) [87].

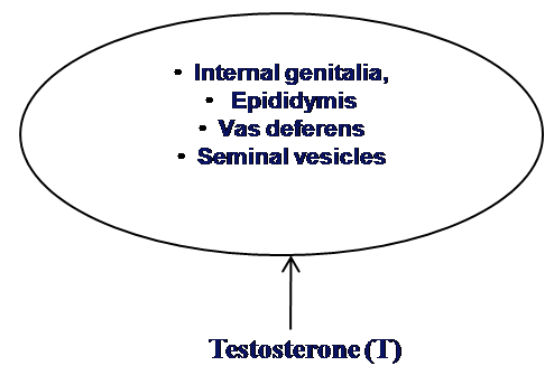

SRD5A2

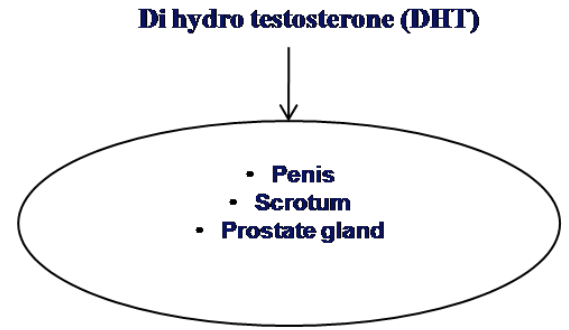

Fig. (4). Role of Androgens ( $\mathrm{T}$ and DHT) in internal and external genitalia development.

\section{Cryptorchidism}

Cryptorchidism is one of the most common congenital anomalies among infertile males. Cryptorchidism is characterized by failure of testicular migration from an abdominal position, through the inguinal canal, into the ipsilateral scrotum during fetal development. It may be unilateral or bilateral. About $30 \%$ of premature infant boys are born with at least one undescendend testis, making cryptorchidism the most common birth defect of male genitalia. Men with a history of cryptorchidism are frequently subfertile in adulthood due to impaired spermatogenesis [88]. A more pronounced damage to spermatogenesis is usually observed in bilateral cryptorchidism. Cryptorchid subjects show reduced sperm concentration, increased FSH and reduced inhibin B plasma levels that correlate to reduced testicular volume in adult life, even after treatment by orchidopexy. Deterioration of fertility potential, as shown by abnormal sperm count, is seen in about $50 \%$ of individuals in unilateral cases and in about $80 \%$ of bilateral ex-cryptorchid males [89]. Cryptorchidism is considered one of the most common causes of non-obstructive azoospermia, accounting for $20 \%$ of such cases [90]. Rare cases of cytogenetic anomalies in 
association with cryptorchidism have been reported; however, the exact genetic mechanism and the candidate genes are still unclear. Mutations in the INSL3 and LGR8 genes which are located on chromosomes 19 and 13, respectively, have been linked to cryptorchidism [91]. Such mutations occur in approximately $5 \%$ of men with cryptorchidism.

\section{Hypogonadism}

Hypogonadism is a condition characterized by decreased gonadal functional activity. When androgen deficiency is the result of testicular failure, the condition is described as primary hypogonadism or hypergonadotrophic hypogonadism. When androgen deficiency is the result of abnormalities in the pituitary/hypothalamus, due to the low levels of $\mathrm{LH}$ and FSH, it is termed secondary hypogonadism or hypogonadotrophic hypogonadism. Primary hypogonadism can be caused by Klinefelter syndrome or impaired testicular development such as in cryptorchidism. Secondary hypogonadism may result from either decreased $\mathrm{GnRH}$ that controls LH and FSH production or decreased production of LH or FSH itself. GnRH is a member of the coupled receptors G-protein family. GnRH gene has seven transmembrane domains, comprising 3 exons, and is located on chromosome $4 q 21.2$. Mutation in this gene is a rare cause of hypogonadism and screening for mutations is not recommended unless there is a family history of hypogonadism. Mutations in the LH or FSH receptor gene are also rarely seen, but this observation may be due to the unusual screening for such mutations since rare mutations in FSH receptor gene and several mutations in $\mathrm{LH}$ receptor gene have been described. LH deficiency causes pseudohermaphroditism, delayed puberty, micropenis and azoospermia whereas FSH deficiency is associated with decreased testicular volume and various stage of impaired spermatogenesis regardless of normal virilization. Another form of hypogonadism is Kallmann syndrome (KS), which is a Xlinked recessive disease with marked genetic heterogeneity.
It is characterized by the association of hypogonadotropic hypogonadism and anosmia. There are at least six genes, KAL1, FGFR1, PROKR2, PROK2, CHD7, and FGF8, known to be associated with KS. KAL1 gene is located on chromosome Xp22.3. and encodes a neural cell adhesion molecule, anosmin-1, which is normally expressed in the brain, facial mesenchyme, mesonephros and metanephros. The location and function of genes implicated in KS are described in Table 2. Mutations involving these genes account for about $25 \%-30 \%$ of all KS. Various KAL1 mutations have been described in hypogonadotrophic hypogonadal males [92-94]. Mutations in FGFR1 or FGF8, encoding fibroblast growth factor receptor-1 and fibroblast growth factor- 8 respectively, underlie an autosomal dominant form of KS with incomplete penetrance. Conversely, mutations in PROKR2 and PROK2, encoding prokineticin receptor-2 and prokineticin-2, have been found in heterozygous, homozygous, and compound heterozygous states respectively. PROKR2 and PROK2 are likely to be involved in both monogenic recessive and digenic/oligogenic $\mathrm{KS}$ transmission, and are responsible for at least $30 \%$ of $\mathrm{KS}$ cases. Patients with $\mathrm{KS}$ are advised to undergo genetic screening based on their phenotype.

\section{Other Genetic Defects}

Although several genetic tests are available for oligozoospermia and azoospermia patients, results in most cases are normal and a substantial proportion of patients are still categorized as idiopathic. It is therefore important to consider other possible genetic defects associated with male infertility. Mutations in Deleted in azoospermia like (DAZL), Methyl-enetetrahydrofolate reductase (MTHFR), Protamine (PRM1 and PRM2), and Transitional protein (TNP1 and TNP2) genes have been associated with male infertility.

DAZL is located on chromosome 3p24 and share homology, with approximately $83 \%$ similarity, to the DAZ gene on $\mathrm{Y}$ chromosome. It is believed that DAZ loci on $\mathrm{Y}$ chromosome are derivative of the autosomal DAZL which

Table 2. Genes Associated with Kallman Syndrome and their Phenotype

\begin{tabular}{|c|c|c|c|c|}
\hline Gene & $\begin{array}{l}\text { Chromosome } \\
\text { Location }\end{array}$ & Protein & Function & Phenotype \\
\hline $\begin{array}{l}\text { KAL1 (KS1): Kallmann } \\
\text { syndrome } 1 \text { sequence }\end{array}$ & $\mathrm{Xp} 22.3$ & anosmin-1 & $\begin{array}{l}\text { Responsible for migration of nerve cell } \\
\text { precursors during embryogenesis }\end{array}$ & $\begin{array}{l}\text { hypothalamichypogonadotropic } \\
\text { hypogonadism, anosmia }\end{array}$ \\
\hline $\begin{array}{l}\text { FGFR1 (KS2): } \\
\text { Fibroblast growth factor } \\
\text { receptor } 1\end{array}$ & $8 \mathrm{p} 12$ & $\begin{array}{l}\text { fibroblast growth } \\
\text { factor receptor } 1\end{array}$ & $\begin{array}{l}\text { Cell division, regulation of cell growth and } \\
\text { maturation, formation of blood vessels, wound } \\
\text { healing, and embryonic development }\end{array}$ & Pfeiffer syndrome \\
\hline $\begin{array}{l}\text { PROKR2 }(\mathrm{KS} 3) \text { : } \\
\text { Prokineticin receptor } 2\end{array}$ & $20 \mathrm{p} 12.3$ & $\begin{array}{l}\text { prokineticin } \\
\text { receptor } 2\end{array}$ & $\begin{array}{l}\text { Trigger a series of chemical signals within the } \\
\text { cell that regulate various cell functions }\end{array}$ & Kallmann syndrome type 3 \\
\hline $\begin{array}{l}\text { PROK2 (KS4): } \\
\text { Prokineticin } 2\end{array}$ & $3 \mathrm{p} 13$ & prokineticin 2 & $\begin{array}{l}\text { Trigger a series of chemical signals within the } \\
\text { cell that regulate various cell functions }\end{array}$ & Kallmann syndrome type 4 \\
\hline $\begin{array}{l}\text { CHD7 (KS5): } \\
\text { Chromodomain helicase } \\
\text { DNA binding protein }\end{array}$ & $8 \mathrm{q} 12.2$ & $\begin{array}{l}\text { chromodomain } \\
\text { helicase DNA } \\
\text { binding protein } 7\end{array}$ & Play a role in the organization of chromatin & CHARGE syndrome \\
\hline $\begin{array}{l}\text { FGF8 (KS6): Fibroblast } \\
\text { growth factor } 8\end{array}$ & $10 \mathrm{q} 24$ & $\begin{array}{l}\text { Fibroblast growth } \\
\text { factor } 8\end{array}$ & $\begin{array}{l}\text { Possess broad mitogenic, cell survival activities, } \\
\text { and are involved in a variety of biological } \\
\text { processes, including embryonic development, cell } \\
\text { growth, morphogenesis, tissue repair, tumor } \\
\text { growth and invasion }\end{array}$ & Tumor growth and angiogensis \\
\hline
\end{tabular}


arose during primate evolution [95]. Moreover, DAZL is believed to be the master regulator of germ line gene expression, as DAZL lead to differentiation of embryonic stem cells into pre- and post-meiotic germ cells [96]. Despite that, studies involving infertile men from different population revealed that DAZL single-nucleotide polymorphisms (SNPs) have been associated with reduced sperm count in the American population [97], whereas no association was found in other Caucasian population [98]. As such, it is still necessary to elucidate the type and role of DAZL variants in different populations.

MTHFR is one of the key enzymes in folate metabolism encoded by MTHFR gene located on chromosome 1p36.3. MTHFR plays an essential role in de novo nucleic acid synthesis of thymidine. Folate deficiency is common and the related hyperhomocysteinaemia is a risk factor for various diseases including male infertility [99, 100]. The most studied variant $(677 \mathrm{C}>\mathrm{T})$ of this gene has been associated with increased blood homocysteine levels, cardiovascular disease, neural defects, schizophrenia, thrombosis and male infertility [101-103]. Infertile patients with hyperhomocysteinaemia can be screened for $677 \mathrm{C}>\mathrm{T}$ and other possible MTHFR variants, and be advised a folate rich diet or folate supplements in case of mutations.

\section{Mitochondrial DNA Mutations}

Sperm mitochondria contain 1-2 mt DNA and are helically arranged around the midpiece. Mitochondrial DNA codes for 37 genes which regulates oxidative phosphorylation. Mitochondrial DNA is unique and differs from the nuclear DNA with respect to replication, repair mechanism, genome packing and position. However, unlike nuclear DNA mitochondrial DNA is not protected by histones and is physically associated with the inner mitochondrial membrane, where highly mutagenic oxygen radicals are generated as byproducts of OXPHOS in the respiratory chain $[104,105]$. The leakage of these free radicals makes mitochondria a major intracellular source of reactive oxygen species (ROS). These unique features are probably the cause of faster accumulation of sequence variations in mitochondrial DNA than in nuclear DNA [106, 107]. PCR amplification of mtDNA has shown a higher incidence of mtDNA deletion in asthenozoospermic patients as compared with unaffected individuals [108]. Recent studies by Shamsi et al. (2008) showed that sperm with motility disorders harbored $\mathrm{mt}$ mutations and had partially formed or totally dysmorphic and disorganized axonemal apparatus [109]. They also reported that men with idiopathic infertility had low antioxidant levels and increased number of mitochondrial sequence variations. Moreover, it is believed that mtDNA mutation may impair electron transport chain resulting in enhanced production of mitochondria ROS due to incomplete reduction of oxygen [110]. This excessive ROS production may induce the opening of membrane permeability transition pores and release of free radicals, cytochrome $\mathrm{C}$ and other apoptogenic factors that ultimately lead to apoptosis. Although mtDNA mutations have been identified in many studies, their role as a diagnostic marker in male infertility is still under debate. Nonetheless, male infertility due to mtDNA mutation can be successfully treated by ICSI, as mtDNA mutations are not transmitted to the offspring.

\section{Sperm DNA Integrity}

Sperm nuclear genome integrity is vital for the accurate transmission of genetic information to the offspring. Unlike somatic cells, sperm chromatin is tightly packaged due to the presence of protamine, an arginine rich protein. Improper DNA packaging may render DNA vulnerable to environmental insult. As a result, sperm DNA integrity is compromised which ultimately impacts the ability of the male gamete to fertilize the oocyte and to form a normal and viable embryo.

A small percentage of spermatozoa from fertile men possess detectable levels of DNA damage $[111,112]$. However, sperm DNA damage is increased in infertile men and approximately $5 \%-15 \%$ of such individuals have complete protamine deficiency $[113,114]$. Sakkas and colleagues have proposed that spermatozoa with DNA damage initiated and subsequently escaped apoptosis [115]. The role of sperm nuclear proteins, the protamines $(\mathrm{P})$ and transitional proteins (TP) in sperm function has been the focus of many recent studies [116-122]. Sperm nuclear proteins play an important role in chromatin condensation during spermiogenesis. A highly condensed sperm chromatin is essential for maintaining sperm DNA integrity [116, 117].

Altered sperm P1/P2 ratio leads to abnormal sperm DNA packing and has been reported to be an important cause of male infertility [123-125]. A possible reason for $\mathrm{P} 1 / \mathrm{P} 2$ altered ratio is an interrupted post-translation modification or mutation in PRM/TNP genes. Although early studies reported rare protamine mutations in association with male infertility, recent observations demonstrated novel mutations and high frequency of single nucleotide polymorphisms (SNPs) in sperm nuclear protein genes (PRM/TNP) [123, 126-129].

DNA damage cannot be analyzed or estimated by conventional cytogenetics or semen analysis. Various tests have been developed to measure sperm DNA damage in the clinical laboratory setting such as sperm chromatin structure assay, sperm chromatin dispersion test, transferase-mediated dTUP nick-end labeling (TUNEL), acridine orange test, acidic and basic dye tests (Table 3). We have established SCSA in our laboratory in India and found that a DFI cutoff level of $30.27 \%$ was able to discriminate infertile and fertile men (unpublished data). Infertile men were found to have higher sperm DNA damage compared to fertile controls (Fig. 5)

Although it is impossible to treat cytogenetic abnormalities and genetic aberrations, sperm oxidative DNA damage to a large extent can be prevented or decreased. This can be done by lifestyle changes such as quitting smoking, decreasing alcohol intake and exercising, by eating antioxidant rich-food and/or treating genital infections and clinical varicocele.

\section{Importance of Genetic Testing and Counselling}

The reasons behind infertility are manifold and a large proportion of cases are still categorized as idiopathic. Genetic testing plays an important role in the evaluation of male infertility not only for diagnosis but also to prevent iatrogenic transmission of the genetic defect to the offspring. Several professional organizations have established recom- 
Table 3. Sperm DNA Integrity Methods, Principle, Merits and Demerits

\begin{tabular}{|c|c|c|c|c|}
\hline Assay type & Principle & Observation & Measurement & Merits/Demerits \\
\hline TUNEL & $\begin{array}{l}\text { Terminal deoxynucleotidyl transferase- } \\
\text { mediated (TdT) deoxyuridine triphosphate } \\
\text { (dUTP) nick end labeling assay. TUNEL is } \\
\text { a direct quantification of sperm DNA breaks }\end{array}$ & $\begin{array}{l}\text { Sperm are classified as TUNEL } \\
\text { positive or negative and expressed as } \\
\text { a percentage of the total sperm in the } \\
\text { population }\end{array}$ & $\begin{array}{l}\text { Percentage cells with } \\
\text { labeled DNA }\end{array}$ & $\begin{array}{l}\text { Can be performed on } \\
\text { few sperm. Expensive } \\
\text { equipment not } \\
\text { required. Thresholds } \\
\text { not standardized. }\end{array}$ \\
\hline SCD & $\begin{array}{l}\text { Individual cells immersed in agarose, } \\
\text { denatured with acid then lysed }\end{array}$ & $\begin{array}{l}\text { Normal sperm produce halo and } \\
\text { sperm which produce a very small } \\
\text { halo or no halo at all contain DNA } \\
\text { fragmentation }\end{array}$ & $\begin{array}{l}\text { Percentage cells with } \\
\text { different grade of Halos }\end{array}$ & $\begin{array}{l}\text { Easy and limited } \\
\text { clinical data }\end{array}$ \\
\hline $\begin{array}{l}\text { Acridine } \\
\text { orange } \\
\text { (AO) test } \\
\text { (Microsopy) }\end{array}$ & $\begin{array}{l}\text { Metachromatic shift of AO from green to } \\
\text { red fluorescence is used to determine extent } \\
\text { of DNA denaturation }\end{array}$ & $\begin{array}{l}\text { Visual interpretation of cells under } \\
\text { fluorescent microscopy }\end{array}$ & $\begin{array}{l}\text { Percentage cells with } \\
\text { green, red and orange } \\
\text { nucleus }\end{array}$ & $\begin{array}{l}\text { Many cells rapidly } \\
\text { examined. Expensive } \\
\text { equipment is required, } \\
\text { time-consuming }\end{array}$ \\
\hline COMET & $\begin{array}{l}\text { Decondensed sperm are suspended in an } \\
\text { agarose gel, subjected to an electrophoretic } \\
\text { gradient, stained with fluorescent DNA- } \\
\text { binding dye }\end{array}$ & $\begin{array}{l}\text { Low-molecular weight DNA, short } \\
\text { fragments of both single-stranded and } \\
\text { double-stranded DNA will migrate } \\
\text { during electrophoresis giving the cha- } \\
\text { racteristic comet tail. High-molecular } \\
\text { weight DNA will not migrate and } \\
\text { remain in the head of the "comet." }\end{array}$ & $\begin{array}{l}\text { Percentage sperm with } \\
\text { long tails (tail length, } \% \\
\text { of DNA in tail) }\end{array}$ & $\begin{array}{l}\text { Sensitive/ but labor } \\
\text { intensive }\end{array}$ \\
\hline SCSA & $\begin{array}{l}\text { DNA in sperm with abnormal chromatin } \\
\text { structure is more prone to acid or heat } \\
\text { denaturation. Using the metachromatic } \\
\text { properties of acridine orange (AO), SCSA } \\
\text { measures susceptibility of sperm DNA to } \\
\text { acid-induced denaturation in situ by running } \\
\text { the sperm cell suspension using flow } \\
\text { cytometry }\end{array}$ & $\begin{array}{l}\text { Metachromatic shift of AO from } \\
\text { green to red fluorescence }\end{array}$ & $\begin{array}{l}\text { Calculation of percent- } \\
\text { age DFI, which is the } \\
\text { ratio of the red fluore- } \\
\text { scence to the sum of red } \\
\text { and green fluorescence }\end{array}$ & $\begin{array}{l}\text { Reproducible results. } \\
\text { Clinically accepted } \\
\text { Expensive equipment }\end{array}$ \\
\hline $\begin{array}{l}\text { In situ nick } \\
\text { translation }\end{array}$ & Similar to TUNEL & $\begin{array}{c}\text { Identifies single-stranded DNA } \\
\text { breaks in a reaction catalyzed by the } \\
\text { template dependent enzyme, DNA } \\
\text { polymerase I }\end{array}$ & & $\begin{array}{c}\text { Simple. } \\
\text { Lacks sensitivity }\end{array}$ \\
\hline
\end{tabular}
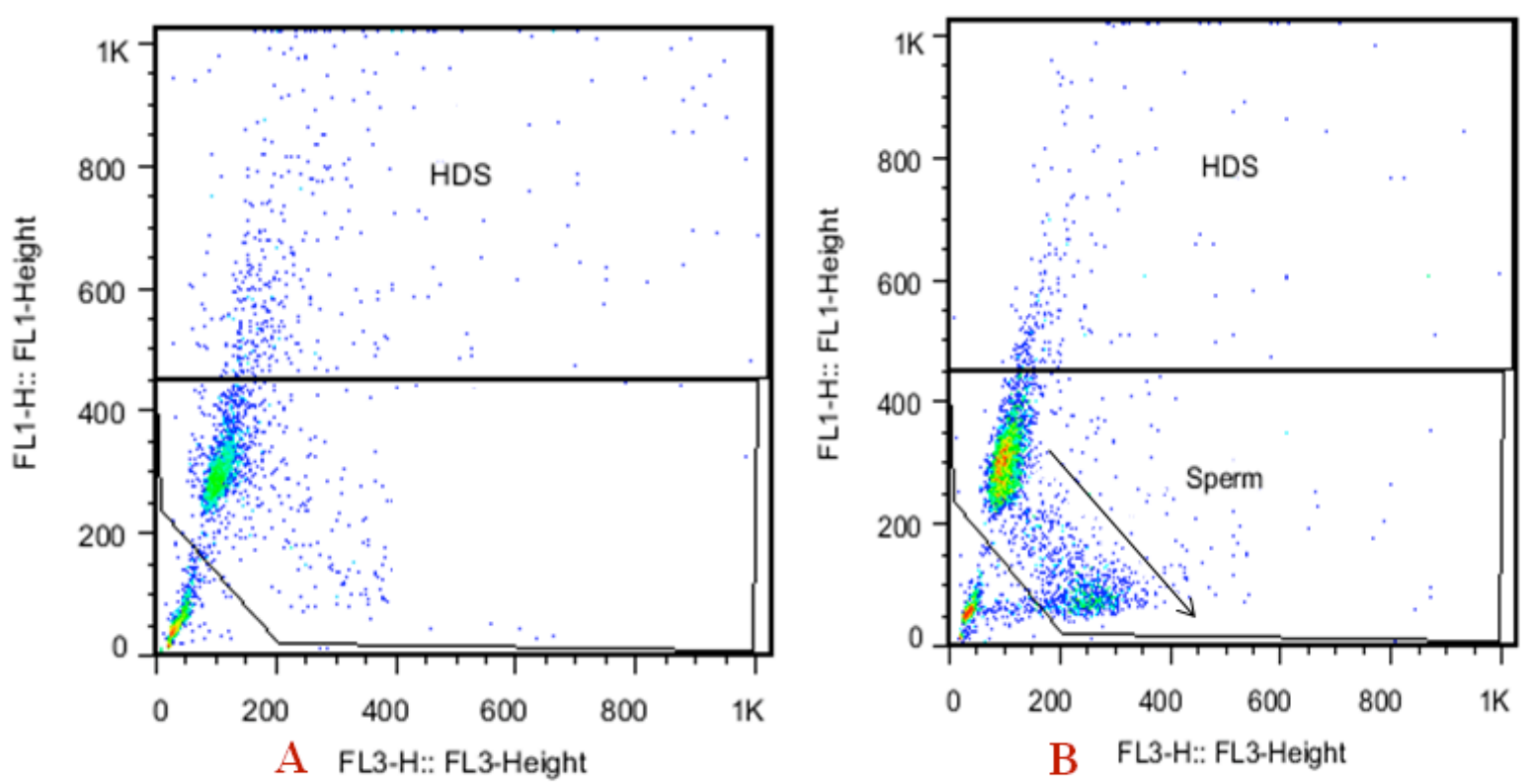

Fig. (5). Pseudo colour plot of green versus red fluorescence of sperm DNA treated with acridine orange by SCSA. A- Fertile control, BInfertile male.

mendations with regard to genetic tests for couples seeking infertility treatment. The European Society of Human Reproduction and Embryology has addressed the issue of 'optimal use of infertility diagnostic test and treatments' in the Capri workshop. The Italian community of professionals, supported by international societies, has created guidelines for the appropriate use of genetic tests in infertile couples in 2002. European Molecular Genetics Quality Network 
Table 4. Recommendations for Various Genetic Testing Based on their Phenotypes

\begin{tabular}{|c|c|c|}
\hline Genetic Test & Phenotype & Recommendations \\
\hline Cytogenetic analysis & Severe oligozoospermia & Mandatory \\
\hline $\begin{array}{l}\text { Sperm- Fluorescent in situ hybridization (FISH)- } \\
\text { meiotic segregation analysis }\end{array}$ & Severe oligozoospermia & $\begin{array}{l}\text { Suggested (in cases with } \\
\text { mosaicism) }\end{array}$ \\
\hline $\begin{array}{l}\text { Cystic fibrosis transmembrane conductance } \\
\text { regulator (CFTR) mutation analysis }\end{array}$ & Congenital bilateral absence of vas deferens (CBAVD) & Highly Recommended \\
\hline KAL1 gene mutation analysis & Kallmann syndrome (KS) & Recommended \\
\hline $\mathrm{CAG}$ repeat/AR gene mutation analysis & Androgen insensitivity syndrome (AIS) & Recommended \\
\hline $\begin{array}{l}\text { Follicle stimulating hormone (FSH) gene mutation } \\
\text { analysis }\end{array}$ & Decreased testicular volume & Suggested \\
\hline $\begin{array}{l}\text { Gonadotropin releasing hormone }(\mathrm{GnRH}) \text { gene } \\
\text { mutation analysis }\end{array}$ & Low serum LH and FSH levels & Suggested \\
\hline $\begin{array}{l}\text { Protamine /transitional nuclear protein gene } \\
\text { mutation analysis }\end{array}$ & Teratozoospermia/ Abnormal $\mathrm{P} 1 / \mathrm{P} 2$ ratio & Suggested \\
\hline $\begin{array}{c}\text { Sperm mitochondrial DNA (mtDNA) mutation } \\
\text { analysis }\end{array}$ & Asthenozoospermia/ Oligozoospermia & Suggested \\
\hline
\end{tabular}

(EMQN) has provided elaborated, disease-specific guidelines (www.emgn.org). Here, we recommend various genetic tests in the evaluation of male infertility (Table 4).

ICSI is the only method for many couples with severe male factor infertility due to genetic defects to achieve a live birth. ART success rates may depend on the type of genetic anomaly. Additionally, there is an increased risk of transmitting genetic defects to the offspring. As such, genetic counseling should be a crucial step prior to embarking on ART. Genetic anomalies (chromosomal aberrations and AZF microdeletion) comprise an important etiological factor which may lead to poor embryo development and blastocyst formation, and fetal loss. Offspring with genital ambiguity was reported in cases with AZF deletion due to Y chromosome instability. In male offspring from AZF deleted father, AZF deletion status should be determined and parents should be informed about semen cryopreservation [130]. Babies conceived via ART have a higher risk for low birth weight, developmental delay, increased incidence of major and minor congenital malformations like neural tube defects, hypospadias and musculoskeletal disorders and increased incidence of certain cancers [131]. There is also a fourfold increase in incidence of sex chromosomal abnormalities and threefold increase in incidence of structural chromosomal defects [131]. A sixfold increase in the incidence of imprinting defects has also been reported babies conceived by
ART/ICSI [132]. This may be due to retrieval of epigenetically immature germ cells from the testes Parental balanced translocations account for the largest percentage of karyotype abnormalities in the fetus [133]. These can result in pregnancy loss because segregation during meiosis results in duplication or deficiency of the chromosome segment. These structural chromosomal anomalies may not have a phenotypic effect on carriers (parents), but result in production of genetically unbalanced gametes, which may result in fetal loss. Studies have shown that the frequency of sex and autosomal chromosomal abnormalities and gene mutation in ART-conceived babies is significantly higher than in babies conceived naturally $[134,135]$. With recent studies emphasizing the role of oxidative stress induced DNA damage, men with high DNA fragmentation index should be counseled towards measures aiming to decrease DNA damage, such as lifestyle modifications and varicocele repair, if clinically present [136].

\section{EXPERT COMMENTARY}

The aim of this article is to highlight the importance of genetic testing in male infertility. Several thousands of single or multiple genes, yet to be identified play an important role in male fertility. Currently, genetic testing at the chromosomal and gene level is available. 
Until about a decade ago the understanding of the genetic basis of infertility was of limited value. In the current era of ART, however, a genetic defect may be transmitted to the offspring. Some genetic defects and DNA damage may lead to increased morbidity, childhood cancer and genital ambiguity. As such, genetic testing in infertile males allow couples to make educated decision regarding choices to use sperm donor or opt for advanced assisted conception techniques if an abnormal result is revealed.

\section{FIVE-YEAR REVIEW}

Advanced assisted reproduction techniques may transmit genetic abnormalities to the offspring that can result in the birth of children with higher risk of infertility, congenital abnormalities and morbidity $[1,4,7]$. Public awareness and importance of genetic testing prior to assisted conception should be initiated. Recently, the role of oxidative stress and oxidative stress induced DNA damage in men with idiopathic infertility has also been recognized [4, 104, 137]. Infertile males should be advised for lifestyle modifications to prevent free radical induced oxidative DNA damage [104]. Apart from nuclear DNA defects, mtDNA defects may also play pathogenic role in male infertility [104]. As such, it is important to distinguish whether an infertile male has nuclear or mitochondrial defect or nonspecific DNA damage to provide appropriate treatment options and genetic counseling.

\section{KEY POINTS}

- Genetic factors may involve mitochondrial or nuclear genes.

- Nuclear DNA defects may be monogenic, chromosomal or syndromic.

- $\quad$ Overall, structural chromosomal abnormalities result in oligozoospermia whereas numerical sex chromosomal abnormalities result in azoospermia.

- Depending on the type of azoospermia being obstructive or non-obstructive one can decide on which genes need to be analysed (e.g. CFTR gene analysis in obstructive azoospermia, Yq microdeletion analysis in non-obstructive azoospermia or severe oligozoospermia).

- $\quad$ MtDNA sequence variations are an important cause of impaired sperm motility, low ATP levels and high ROS production.

- $\quad$ Sperm nuclei peripheral region has critical histonebound genes for early embryonic development which are more prone to oxidative DNA damage.

- Early diagnosis and prompt antioxidant treatment can result in significant decline in free radical levels and oxidative DNA damage.

- $\quad$ Oxidative DNA damage can result in sperm methylation errors that may explain the increased incidence of imprinting defects in ART conceived children.

- Genetic testing in infertile males allow couples to make educated decision regarding the choices to use sperm donor or opt for advanced assisted conception techniques if an abnormal result is revealed.

\section{ACKNOWLEDGEMENTS}

None Declared.

\section{CONFLICT OF INTEREST}

None Declared.

\section{REFERENCES}

[1] Dada R, Kumar R, Shamsi MB, et al. Genetic screening in couples experiencing recurrent assisted procreation failure. Indian $\mathrm{J}$ Biochem Biophys 2008; 45: 116-20.

[2] Matzuk MM, Lamb DJ. Genetic dissection of mammalian fertility pathways. Nat Cell Biol 2002; 4 (Suppl 1): 41-9.

[3] Ferlin A, Raicu F, Gatta V, Zuccarello D, Palka G, Foresta C. Male infertility: role of genetic background. Reprod Biomed Online 2007; 14(6): 734-45

[4] Aitken RJ, Krausz C. Oxidative stress, DNA damage and the Y chromosome. Reproduction 2001; 122(4): 497-506.

[5] Schultz RM, Williams CJ. The science of ART. Science 2002; 296(5576): 2188-90.

[6] Lissitsina J, Mikelsaar R, Punab M. Cytogenetic analyses in infertile men. Arch Androl 2006; 52(2): 91-5.

[7] Dada R, Shamsi MB, Venkatesh S, Eds. Genetics of male Infertility. New Delhi: Jaypee Brothers Medical Publishers 2010.

[8] Kumar R, Bhat A, Bamezai RN, et al. Necessity of nuclear and mitochondrial genome analysis prior to assisted reproductive techniques/intracytoplasmic sperm injection. Indian J Biochem Biophys 2007; 44(6): 437-42.

[9] Nakamura Y, Kitamura M, Nishimura K, et al. Chromosomal variants among 1790 infertile men. Int J Urol 2001; 8(2): 49-52.

[10] Balkan M, Tekes S, Gedik A. Cytogenetic and Y chromosome microdeletion screening studies in infertile males with Oligozoospermia and Azoospermia in Southeast Turkey. J Assist Reprod Genet 2008; 25(11-12): 559-65.

[11] Akgul M, Ozkinay F, Ercal D, et al. Cytogenetic abnormalities in 179 cases with male infertility in Western Region of Turkey: report and review. J Assist Reprod Genet 2009; 26(2-3): 119-22.

[12] Rives N, Joly G, Machy A, Simeon N, Leclerc P, Mace B. Assessment of sex chromosome aneuploidy in sperm nuclei from 47,XXY and 46,XY/47,XXY males: comparison with fertile and infertile males with normal karyotype. Mol Hum Reprod 2000; 6(2): 107-12.

[13] Martinez-Garza SG, Gallegos-Rivas MC, Vargas-Maciel M, et al. Genetic screening in infertile Mexican men: chromosomal abnormalities, Y chromosome deletions, and androgen receptor CAG repeat length. J Androl 2008; 29(6): 654-60.

[14] Schiff JD, Palermo GD, Veeck LL, Goldstein M, Rosenwaks Z, Schlegel PN. Success of testicular sperm extraction and intracytoplasmic sperm injection in men with Klinefelter syndrome. J Clin Endocrinol Metab 2005; 90(11): 6263-7.

[15] Ron-El R, Strassburger D, Gelman-Kohan S, Friedler S, Raziel A, Appelman Z. A 47,XXY fetus conceived after ICSI of spermatozoa from a patient with non-mosaic Klinefelter's syndrome: case report. Hum Reprod 2000; 15(8): 1804-6.

[16] Ron-El R, Raziel A, Strassburger D, Schachter M, Bern O, Friedler S. Birth of healthy male twins after intracytoplasmic sperm injection of frozen-thawed testicular spermatozoa from a patient with nonmosaic Klinefelter syndrome. Fertil Steril 2000; 74(4): 832-3.

[17] Friedler S, Raziel A, Strassburger D, Schachter M, Bern O, Ron-El R. Outcome of ICSI using fresh and cryopreserved-thawed testicular spermatozoa in patients with non-mosaic Klinefelter's syndrome. Hum Reprod 2001; 16(12): 2616-20.

[18] Sciurano RB, Hisano LCV, Rahn MI, et al. Focal spermatogenesis originates in euploid germ cells in classical Klinefelter patients. Hum Reprod 2009; 24(9): 2353-60.

[19] Lim AS, Fong Y, Yu SL. Estimates of sperm sex chromosome disomy and diploidy rates in a 47,XXY/46,XY mosaic Klinefelter patient. Hum Genet 1999; 104(5): 405-9. 
[20] Kruse R, Guttenbach M, Schartmann B, et al. Genetic counseling in a patient with $\mathrm{XXY} / \mathrm{XXXY} / \mathrm{XY}$ mosaic Klinefelter's syndrome: estimate of sex chromosome aberrations in sperm before intracytoplasmic sperm injection. Fertil Steril 1998; 69(3): 482-5.

[21] Estop AM, Munne S, Cieply KM, Vandermark KK, Lamb AN, Fisch H. Meiotic products of a Klinefelter 47, XXY male as determined by sperm fluorescence in-situ hybridization analysis. Hum Reprod 1998; 13(1): 124-7.

[22] Lenz P, Luetjens CM, Kamischke A, Kuhnert B, Kennerknecht I, Nieschlag E. Mosaic status in lymphocytes of infertile men with or without Klinefelter syndrome. Hum Reprod 2005; 20(5): 1248-55.

[23] Dada R, Kumar R, Ahmed ME, et al. Klinefelter Syndrome: Clinical Implications of Expanding Phenotype. Indian J Practising Doctor 2007; 3(6): 1-2.

[24] Thomas NS, Hassold TJ. Aberrant recombination and the origin of Klinefelter syndrome. Hum Reprod Update 2003; 9(4): 309-17.

[25] Tuttelmann F, Gromoll J. Novel genetic aspects of Klinefelter's syndrome. Mol Hum Reprod 2010; 16(6): 386-95.

[26] Ichioka K, Utsunomiya N, Kohei N, Ueda N, Inoue K, Terai A. Adult onset of declining spermatogenesis in a man with nonmosaic Klinefelter's syndrome. Fertil Steril 2006; 85(5): 1511 e1-2.

[27] Gabriel-Robez O, Ratomponirina C, Dutrillaux B, Carre-Pigeon F, Rumpler Y. Meiotic association between the XY chromosomes and the autosomal quadrivalent of a reciprocal translocation in two infertile men, 46,XY,t(19;22) and 46,XY,t(17;21). Cytogenet Cell Genet 1986; 43(3-4): 154-60.

[28] Estop AM, Van Kirk V, Cieply K. Segregation analysis of four translocations, $\mathrm{t}(2 ; 18), \mathrm{t}(3 ; 15), \mathrm{t}(5 ; 7)$, and $\mathrm{t}(10 ; 12)$, by sperm chromosome studies and a review of the literature. Cytogenet Cell Genet 1995; 70(1-2): 80-7.

[29] Martin RH, Spriggs EL. Sperm chromosome complements in a man heterozygous for a reciprocal translocation 46,XY,t $(9 ; 13)$ (q21.1;q21.2) and a review of the literature. Clin Genet 1995; 47(1): 42-6.

[30] Cifuentes P, Navarro J, Blanco J, et al. Cytogenetic analysis of sperm chromosomes and sperm nuclei in a male heterozygous for a reciprocal translocation $\mathrm{t}(5 ; 7)(\mathrm{q} 21 ; \mathrm{q} 32)$ by in situ hybridisation. Eur J Hum Genet 1999; 7(2): 231-8.

[31] Alves C, Carvalho F, Cremades N, Sousa M, Barros A. Unique $(\mathrm{Y} ; 13)$ translocation in a male with oligozoospermia: cytogenetic and molecular studies. Eur J Hum Genet 2002; 10(8): 467-74.

[32] Chandley AC, Seuanez H, Fletcher JM. Meiotic behavior of five human reciprocal translocations. Cytogenet Cell Genet 1976; 17(2): 98-111.

[33] Elliott DJ, Cooke HJ. The molecular genetics of male infertility. Bioessays 1997; 19(9): 801-9.

[34] Ferguson KA, Chow V, Ma S. Silencing of unpaired meiotic chromosomes and altered recombination patterns in an azoospermic carrier of a $\mathrm{t}(8 ; 13)$ reciprocal translocation. Hum Reprod 2008; 23(4): 988-95.

[35] Baccetti B, Bruni E, Collodel G, et al. 10, 15 reciprocal translocation in an infertile man: ultrastructural and fluorescence in-situ hybridization sperm study: case report. Hum Reprod 2003; 18(11): 2302-8.

[36] Bettio D, Venci A, Rizzi N, Negri L, Setti PL. Clinical and molecular cytogenetic studies in three infertile patients with mosaic rearranged Y chromosomes. Hum Reprod 2006; 21(4): 972-5.

[37] Guo JH, Zhu PY, Huang YF, Yu L. Autosomal aberrations associated with testicular dysgenesis or spermatogenic arrest in Chinese patients. Asian J Androl 2002; 4(1): 3-7.

[38] Nielsen J, Rasmussen K. Autosomal reciprocal translocations and 13/14 translocations: a population study. Clin Genet 1976; 10(3): 161-77.

[39] Lee JY, Dada R, Sabanegh E, Carpi A, Agarwal A. Role of genetics in azoospermia. Urology 2010; 30: (In Press).

[40] Gunel M, Cavkaytar S, Ceylaner G, Batioglu S. Azoospermia and cryptorchidism in a male with a de novo reciprocal $t(\mathrm{Y} ; 16)$ translocation. Genet Couns 2008; 19(3): 277-80.

[41] Pabst B, Glaubitz R, Schalk T, Schneider U, Schulze W, Miller K. Reciprocal translocation between $\mathrm{Y}$ chromosome long arm euchromatin and the short arm of chromosome 1. Ann Genet 2002; 45(1): 5-8.

[42] Mohandas TK, Speed RM, Passage MB, Yen PH, Chandley AC, Shapiro LJ. Role of the pseudoautosomal region in sexchromosome pairing during male meiosis: meiotic studies in a man with a deletion of distal Xp. Am J Hum Genet 1992; 51(3): 526-33.
[43] Dutrillaux B, Gueguen J. Mitotic and meiotic analysis of an Yautosome translocation(author's transl). Humangenetik 1975; 27(3): 241-5.

[44] Therman E, Susman B, Denniston C. The nonrandom participation of human acrocentric chromosomes in Robertsonian translocations. Ann Hum Genet 1989; 53(Pt 1): 49-65.

[45] Neri G, Ricci R, Pelino A, Bova R, Tedeschi B, Serra A. A boy with ring chromosome 15 derived from a $\mathrm{t}(15 \mathrm{q} ; 15 \mathrm{q})$ Robertsonian translocation in the mother: cytogenetic and biochemical findings. Am J Med Genet 1983; 14(2): 307-14.

[46] Daniel A, Hook EB, Wulf G. Risks of unbalanced progeny at amniocentesis to carriers of chromosome rearrangements: data from United States and Canadian laboratories. Am J Med Genet 1989; 33(1): 14-53.

[47] Martin RH. Cytogenetic analysis of sperm from a male heterozygous for a 13;14 Robertsonian translocation. Hum Genet 1988; 80(4): 357-61.

[48] Conn CM, Cozzi J, Harper JC, Winston RM, Delhanty JD. Preimplantation genetic diagnosis for couples at high risk of Down syndrome pregnancy owing to parental translocation or mosaicism. J Med Genet 1999; 36(1): 45-50.

[49] Huang J, Lian Y, Qiao J, Chen Y, Ren X, Liu P. Characteristics of embryo development in Robertsonian translocations' preimplantation genetic diagnosis cycles. Prenat Diagn 2009; 29(12): 1167-70.

[50] Pang MG, Hoegerman SF, Cuticchia AJ, et al. Detection of aneuploidy for chromosomes $4,6,7,8,9,10,11,12,13,17,18,21$, $\mathrm{X}$ and $\mathrm{Y}$ by fluorescence in-situ hybridization in spermatozoa from nine patients with oligoasthenoteratozoospermia undergoing intracytoplasmic sperm injection. Hum Reprod 1999; 14(5): 126673.

[51] Scriven PN, Flinter FA, Braude PR, Ogilvie CM. Robertsonian translocations--reproductive risks and indications for preimplantation genetic diagnosis. Hum Reprod 2001; 16(11): 2267-73.

[52] Collodel G, Giannerini V, Pascarelli AN, Federico MG, Comodo F, Moretti E. TEM and FISH studies in sperm from men of couples with recurrent pregnancy loss. Andrologia 2009; 41(6): 352-60.

[53] Sarrate Z, Vidal F, Blanco J. Role of sperm fluorescent in situ hybridization studies in infertile patients: indications, study approach, and clinical relevance. Fertil Steril 2010; 93(6): 1892902.

[54] Rodrigo L, Peinado V, Mateu E, et al. Impact of different patterns of sperm chromosomal abnormalities on the chromosomal constitution of preimplantation embryos. Fertil Steril 2010; 94(4): 1380-6.

[55] Sun C, Skaletsky H, Rozen S, et al. Deletion of azoospermia factor a (AZFa) region of human $\mathrm{Y}$ chromosome caused by recombination between HERV15 proviruses. Hum Mol Genet 2000; 9(15): 2291-6.

[56] Dada R, Gupta NP, Kucheria K. Yq microdeletions--azoospermia factor candidate genes and spermatogenic arrest. J Biomol Tech 2004; 15(3): 176-83

[57] Simoni M, Bakker E, Eurlings MC, et al. Laboratory guidelines for molecular diagnosis of $\mathrm{Y}$-chromosomal microdeletions. Int $\mathrm{J}$ Androl 1999; 22(5): 292-9.

[58] Kamp C, Huellen K, Fernandes S, et al. High deletion frequency of the complete AZFa sequence in men with Sertoli-cell-only syndrome. Mol Hum Reprod 2001; 7(10): 987-94.

[59] Krausz C, Forti G, McElreavey K. The Y chromosome and male fertility and infertility. Int J Androl 2003; 26(2): 70-5.

[60] Krausz C, Quintana-Murci L, McElreavey K. Prognostic value of Y deletion analysis: what is the clinical prognostic value of $\mathrm{Y}$ chromosome microdeletion analysis? Hum Reprod 2000; 15(7): 1431-4.

[61] Calogero AE, Garofalo MR, Barone N, et al. Spontaneous regression over time of the germinal epithelium in a $\mathrm{Y}$ chromosome-microdeleted patient: Case report. Hum Reprod 2001; 16(9): 1845-8.

[62] Foresta C, Ferlin A, Moro E, Marin P, Rossi A, Scandellari C. Microdeletion of chromosome $\mathrm{Y}$ in male infertility: role of the DAZ gene. Ann Ital Med Int 2001; 16(2): 82-92.

[63] Vogt PH. AZF deletions and Y chromosomal haplogroups: history and update based on sequence. Hum Reprod Update 2005; 11(4): 319-36.

[64] Komori S, Kato H, Kobayashi S, Koyama K, Isojima S. Transmission of $\mathrm{Y}$ chromosomal microdeletions from father to son 
through intracytoplasmic sperm injection. J Hum Genet 2002; 47(9): 465-8.

[65] Dada R, Kumar R, Shamsi MB, et al. Higher frequency of Yq microdeletions in sperm DNA as compared to DNA isolated from blood. Asian J Androl 2007; 9(5): 720-2.

[66] Kent-First M, Muallem A, Shultz J, et al. Defining regions of the Y-chromosome responsible for male infertility and identification of a fourth $\mathrm{AZF}$ region (AZFd) by $\mathrm{Y}$-chromosome microdeletion detection. Mol Reprod Dev 1999; 53(1): 27-41.

[67] Carrell DT, De Jonge C, Lamb DJ. The genetics of male infertility: a field of study whose time is now. Arch Androl 2006; 52(4): 26974.

[68] Radpour R, Gourabi H, Gilani MA, Dizaj AV. Molecular study of (TG)m(T)n polymorphisms in Iranian males with congenital bilateral absence of the vas deferens. J Androl 2007; 28(4): 541-7.

[69] Lee $\mathrm{CH}, \mathrm{Wu} \mathrm{CC}, \mathrm{Wu} \mathrm{YN}$, Chiang HS. Gene copy number variations in Asian patients with congenital bilateral absence of the vas deferens. Hum Reprod 2009; 24(3): 748-55.

[70] Uzun S, Gokce S, Wagner K. Cystic fibrosis transmembrane conductance regulator gene mutations in infertile males with congenital bilateral absence of the vas deferens. Tohoku J Exp Med 2005; 207(4): 279-85.

[71] Technical Bulletin - American Society for Reproductive Medicine. Evaluation of the azoospermic male. Fertil Steril 2008; 90: S74-7.

[72] Chillon M, Casals T, Mercier B, et al. Mutations in the cystic fibrosis gene in patients with congenital absence of the vas deferens. N Engl J Med 1995; 332(22): 1475-80.

[73] Galani A, Kitsiou-Tzeli S, Sofokleous C, Kanavakis E, KalpiniMavrou A. Androgen insensitivity syndrome: clinical features and molecular defects. Hormones (Athens) 2008; 7(3): 217-29.

[74] Nenonen H, Bjork C, Skjaerpe PA, et al. CAG repeat number is not inversely associated with androgen receptor activity in vitro. Mol Hum Reprod 2010; 16(3): 153-7.

[75] Lehmann DJ, Butler HT, Warden DR, et al. Association of the androgen receptor CAG repeat polymorphism with Alzheimer's disease in men. Neurosci Lett 2003; 340(2): 87-90.

[76] Sircar K, Gottlieb B, Alvarado C, et al. Androgen receptor CAG repeat length contraction in diseased and non-diseased prostatic tissues. Prostate Cancer Prostatic Dis 2007; 10(4): 360-8.

[77] Hiort O, Holterhus PM, Horter T, et al. Significance of mutations in the androgen receptor gene in males with idiopathic infertility. $\mathrm{J}$ Clin Endocrinol Metab 2000; 85(8): 2810-5.

[78] Mifsud A, Sim CK, Boettger-Tong H, et al. Trinucleotide (CAG) repeat polymorphisms in the androgen receptor gene: molecular markers of risk for male infertility. Fertil Steril 2001; 75(2): 27581 .

[79] Loy CJ, Yong EL. Sex, infertility and the molecular biology of the androgen receptor. Curr Opin Obstet Gynecol 2001; 13(3): 315-21.

[80] Sharma V, Singh R, Thangaraj K, Jyothy A. A novel Arg615Ser mutation of androgen receptor DNA-binding domain in three $46, \mathrm{XY}$ sisters with complete androgen insensitivity syndrome and bilateral inguinal hernia. Fertil Steril 2011; 95(2): 804.e19-21.

[81] Gottlieb B, Lombroso R, Beitel LK, Trifiro MA. Molecular pathology of the androgen receptor in male (in)fertility. Reprod Biomed Online 2005; 10(1): 42-8.

[82] Yong EL, Loy CJ, Sim KS. Androgen receptor gene and male infertility. Hum Reprod Update 2003; 9(1): 1-7.

[83] Ferlin A, Bartoloni L, Rizzo G, Roverato A, Garolla A, Foresta C. Androgen receptor gene $\mathrm{CAG}$ and GGC repeat lengths in idiopathic male infertility. Mol Hum Reprod 2004; 10(6): 417-21.

[84] Holdcraft RW, Braun RE. Androgen receptor function is required in Sertoli cells for the terminal differentiation of haploid spermatids. Development 2004; 131(2): 459-67.

[85] Cram DS, Song B, McLachlan RI, Trounson AO. CAG trinucleotide repeats in the androgen receptor gene of infertile men exhibit stable inheritance in female offspring conceived after ICSI. Mol Hum Reprod 2000; 6(9): 861-6.

[86] Kim SH, Kim KS, Kim GH, Kang BM, Yoo HW. A novel frameshift mutation in the 5alpha-reductase type 2 gene in Korean sisters with male pseudohermaphroditism. Fertil Steril 2006; 85(3): 750 e9- e12.

[87] Sahu R, Boddula R, Sharma P, et al. Genetic analysis of the SRD5A2 gene in Indian patients with 5alpha-reductase deficiency. J Pediatr Endocrinol Metab 2009; 22(3): 247-54.

[88] La Vignera S, Calogero AE, Condorelli R, et al. Cryptorchidism and its long-term complications. Eur Rev Med Pharmacol Sci 2009; 13(5): 351-6.
[89] Caroppo E, Niederberger C, Elhanbly S, Schoor R, Ross L, D'Amato G. Effect of cryptorchidism and retractile testes on male factor infertility: a multicenter, retrospective, chart review. Fertil Steril 2005; 83(5): 1581-4.

[90] Hadziselimovic F. Early successful orchidopexy does not prevent from developing azoospermia. Int Braz J Urol 2006; 32(5): 570-3.

[91] Ferlin A, Zuccarello D, Garolla A, Selice R, Foresta C. Hormonal and genetic control of testicular descent. Reprod Biomed Online 2007; 15(6): 659-65.

[92] Massin N, Pecheux C, Eloit C, et al. X chromosome-linked Kallmann syndrome: clinical heterogeneity in three siblings carrying an intragenic deletion of the KAL-1 gene. J Clin Endocrinol Metab 2003; 88(5): 2003-8.

[93] Albuisson J, Pecheux C, Carel JC, et al. Kallmann syndrome: 14 novel mutations in KAL1 and FGFR1 (KAL2). Hum Mutat 2005; 25(1): 98-9.

[94] Trarbach EB, Baptista MT, Garmes HM, Hackel C. Molecular analysis of KAL-1, GnRH-R, NELF and EBF2 genes in a series of Kallmann syndrome and normosmic hypogonadotropic hypogonadism patients. J Endocrinol 2005; 187(3): 361-8.

[95] Saxena R, Brown LG, Hawkins T, et al. The DAZ gene cluster on the human $\mathrm{Y}$ chromosome arose from an autosomal gene that was transposed, repeatedly amplified and pruned. Nat Genet 1996; 14(3): 292-9.

[96] Kerr CL, Cheng L. The dazzle in germ cell differentiation. J Mol Cell Biol 2010; 2(1): 26-9.

[97] Tung JY, Rosen MP, Nelson LM, et al. Novel missense mutations of the Deleted-in-AZoospermia-Like (DAZL) gene in infertile women and men. Reprod Biol Endocrinol 2006; 4: 40.

[98] Tschanter P, Kostova E, Luetjens CM, Cooper TG, Nieschlag E, Gromoll J. No association of the A260G and A386G DAZL single nucleotide polymorphisms with male infertility in a Caucasian population. Hum Reprod 2004; 19(12): 2771-6.

[99] Safarinejad MR, Shafiei N, Safarinejad S. Relationship between genetic polymorphisms of methylenetetrahydrofolate reductase (C677T, A1298C, and G1793A) as risk factors for idiopathic male infertility. Reprod Sci 2011; 18(3): 304-15.

[100] Singh K, Singh SK, Raman R. MTHFR A1298C polymorphism and idiopathic male infertility. J Postgrad Med 2010; 56(4): 267-9.

[101] Yang QH, Botto LD, Gallagher M, et al. Prevalence and effects of gene-gene and gene-nutrient interactions on serum folate and serum total homocysteine concentrations in the United States: findings from the third National Health and Nutrition Examination Survey DNA Bank. Am J Clin Nutr 2008; 88(1): 232-46.

[102] Park JH, Lee HC, Jeong YM, et al. MTHFR C677T polymorphism associates with unexplained infertile male factors. J Assist Reprod Genet 2005; 22(9-10): 361-8.

[103] A ZC, Yang Y, Zhang SZ, Li N, Zhang W. Single nucleotide polymorphism $\mathrm{C} 677 \mathrm{~T}$ in the methylenetetrahydrofolate reductase gene might be a genetic risk factor for infertility for Chinese men with azoospermia or severe oligozoospermia. Asian J Androl 2007; 9(1): 57-62.

[104] Venkatesh S, Deecaraman M, Kumar R, Shamsi MB, Dada R. Role of reactive oxygen species in the pathogenesis of mitochondrial DNA (mtDNA) mutations in male infertility. Indian J Med Res 2009; 129(2): 127-37.

[105] Richter C, Suter M, Walter PB. Mitochondrial free radical damage and DNA repair. Biofactors 1998; 7(3): 207-8.

[106] Wallace DC, Brown MD, Lott MT. Mitochondrial genetics. London: Churchill Livingstone 1997.

[107] Neckelmann N, Li K, Wade RP, Shuster R, Wallace DC. cDNA sequence of a human skeletal muscle ADP/ATP translocator: lack of a leader peptide, divergence from a fibroblast translocator cDNA, and coevolution with mitochondrial DNA genes. Proc Natl Acad Sci USA 1987; 84(21): 7580-4.

[108] Kao S, Chao HT, Wei YH. Mitochondrial deoxyribonucleic acid 4977-bp deletion is associated with diminished fertility and motility of human sperm. Biol Reprod 1995; 52(4): 729-36.

[109] Shamsi MB, Kumar R, Bhatt A, et al. Mitochondrial DNA Mutations in etiopathogenesis of male infertility. Indian $\mathrm{J}$ Urol 2008; 24(2): 150-4.

[110] Tatton WG, Olanow CW. Apoptosis in neurodegenerative diseases: the role of mitochondria. Biochim Biophys Acta 1999; 1410(2): 195-213.

[111] Spano M, Bonde JP, Hjollund HI, Kolstad HA, Cordelli E, Leter G. Sperm chromatin damage impairs human fertility. The Danish First Pregnancy Planner Study Team. Fertil Steril 2000; 73(1): 43-50. 
[112] Zini A, Bielecki R, Phang D, Zenzes MT. Correlations between two markers of sperm DNA integrity, DNA denaturation and DNA fragmentation, in fertile and infertile men. Fertil Steril 2001; 75(4): 674-7.

[113] Oliva R. Protamines and male infertility. Hum Reprod Update 2006; 12(4): 417-35.

[114] Carrell DT, Liu L. Altered protamine 2 expression is uncommon in donors of known fertility, but common among men with poor fertilizing capacity, and may reflect other abnormalities of spermiogenesis. J Androl 2001; 22(4): 604-10.

[115] Sakkas D, Seli E, Manicardi GC, Nijs M, Ombelet W, Bizzaro D. The presence of abnormal spermatozoa in the ejaculate: did apoptosis fail? Hum Fertil (Camb) 2004; 7(2): 99-103.

[116] Giwercman A, Richthoff J, Hjollund H, et al. Correlation between sperm motility and sperm chromatin structure assay parameters. Fertil Steril 2003; 80(6): 1404-12.

[117] Moskovtsev SI, Willis J, Azad A, Mullen JB. Sperm DNA integrity: correlation with sperm plasma membrane integrity in semen evaluated for male infertility. Arch Androl 2005; 51(1): 3340.

[118] Zhao M, Shirley CR, Yu YE, et al. Targeted disruption of the transition protein 2 gene affects sperm chromatin structure and reduces fertility in mice. Mol Cell Biol 2001; 21(21): 7243-55.

[119] Tseden K, Topaloglu O, Meinhardt A, et al. Premature translation of transition protein 2 mRNA causes sperm abnormalities and male infertility. Mol Reprod Dev 2007; 74(3): 273-9.

[120] Hammoud S, Liu L, Carrell DT. Protamine ratio and the level of histone retention in sperm selected from a density gradient preparation. Andrologia 2009; 41(2): 88-94.

[121] Haraguchi T, Ishikawa T, Yamaguchi K, Fujisawa M. Cyclin and protamine as prognostic molecular marker for testicular sperm extraction in patients with azoospermia. Fertil Steril 2009; 91(4 Suppl): 1424-6.

[122] Tavalaee M, Razavi S, Nasr-Esfahani MH. Influence of sperm chromatin anomalies on assisted reproductive technology outcome. Fertil Steril 2009; 91(4): 1119-26.

[123] Mengual L, Ballesca JL, Ascaso C, Oliva R. Marked differences in protamine content and $\mathrm{P} 1 / \mathrm{P} 2$ ratios in sperm cells from percoll fractions between patients and controls. J Androl 2003; 24(3): 43847.

[124] Steger K, Wilhelm J, Konrad L, et al. Both protamine-1 to protamine- 2 mRNA ratio and Bcl 2 mRNA content in testicular spermatids and ejaculated spermatozoa discriminate between fertile and infertile men. Hum Reprod 2008; 23(1): 11-6.
[125] Zhang X, Gabriel SM, Zini A. Sperm nuclear histone to protamine ratio in fertile and infertile men: evidence of heterogeneous subpopulations of spermatozoa in the ejaculate. J Androl 2006; 27(3): 414-20.

[126] Adham IM, Nayernia K, Burkhardt-Gottges E, et al. Teratozoospermia in mice lacking the transition protein 2 (Tnp2). Mol Hum Reprod 2001; 7(6): 513-20.

[127] Aoki VW, Christensen GL, Atkins JF, Carrell DT. Identification of novel polymorphisms in the nuclear protein genes and their relationship with human sperm protamine deficiency and severe male infertility. Fertil Steril 2006; 86(5): 1416-22.

[128] Cho C, Willis WD, Goulding EH, et al. Haploinsufficiency of protamine-1 or -2 causes infertility in mice. Nat Genet $2001 ; 28(1)$ : 82-6.

[129] Nasr-Esfahani MH, Razavi S, Mardani M, Shirazi R, Javanmardi S. Effects of failed oocyte activation and sperm protamine deficiency on fertilization post-ICSI. Reprod Biomed Online 2007; 14(4): 422-9.

[130] Patsalis PC, Sismani C, Quintana-Murci L, Taleb-Bekkouche F, Krausz C, McElreavey $\mathrm{K}$. Effects of transmission of $\mathrm{Y}$ chromosome AZFc deletions. Lancet 2002; 360(9341): 1222-4.

[131] Hansen RS, Laird CD. A new regulatory pathway for fragile $X$ syndrome? Nat Med 2002; 8(11): 1204-5.

[132] Edwards RG. Genetics, epigenetics and gene silencing in differentiating mammalian embryos. Reprod Biomed Online 2006; 13(5): $732-53$.

[133] Silverstein S, Lerer I, Sagi M, Frumkin A, Ben-Neriah Z, Abeliovich D. Uniparental disomy in fetuses diagnosed with balanced Robertsonian translocations: risk estimate. Prenat Diagn 2002; 22(8): 649-51.

[134] Aboulghar H, Aboulghar M, Mansour R, Serour G, Amin Y, AlInany $\mathrm{H}$. A prospective controlled study of karyotyping for 430 consecutive babies conceived through intracytoplasmic sperm injection. Fertil Steril 2001; 76(2): 249-53.

[135] Feng C, Wang LQ, Dong MY, Huang HF. Assisted reproductive technology may increase clinical mutation detection in male offspring. Fertil Steril 2008; 90(1): 92-6.

[136] Dada R, Shamsi MB, Venkatesh S. Attenuation of oxidative stress \& DNA damage in varicocelectomy: Implications in infertility management. Indian J Med Res 2010; (132): 728-30.

[137] Venkatesh S, Riyaz AM, Shamsi MB, et al. Clinical significance of reactive oxygen species in semen of infertile Indian men. Andrologia 2009; 41(4): 251-6.

Received: January 02, 2010

Revised: March 08, 2010

Accepted: July 26, 2010

(C) Dada et al.; Licensee Bentham Open.

This is an open access article licensed under the terms of the Creative Commons Attribution Non-Commercial License (http://creativecommons.org/licenses/by$\mathrm{nc} / 3.0 /$ ), which permits unrestricted, non-commercial use, distribution and reproduction in any medium, provided the work is properly cited. 